\title{
First results of the Piton de la Fournaise STRAP 2015 experiment: multidisciplinary tracking of a volcanic gas and aerosol plume
}

\author{
Pierre Tulet $^{1}$, Andréa Di Muro ${ }^{2}$, Aurélie Colomb ${ }^{3}$, Cyrielle Denjean $^{4}$, Valentin Duflot ${ }^{1}$, Santiago Arellano $^{5}$, \\ Brice Foucart $^{1,3}$, Jérome Brioude ${ }^{1}$, Karine Sellegri ${ }^{3}$, Aline Peltier ${ }^{2}$, Alessandro Aiuppa ${ }^{6,7}$, Christelle Barthe ${ }^{1}$, \\ Chatrapatty Bhugwant ${ }^{8}$, Soline Bielli ${ }^{1}$, Patrice Boissier ${ }^{2}$, Guillaume Boudoire ${ }^{2}$, Thierry Bourrianne ${ }^{4}$, \\ Christophe Brunet ${ }^{2}$, Fréderic Burnet ${ }^{4}$, Jean-Pierre Cammas ${ }^{1,9}$, Franck Gabarrot ${ }^{9}$, Bo Galle ${ }^{5}$, Gaetano Giudice ${ }^{7}$, \\ Christian Guadagno $^{8}$, Fréderic Jeamblu ${ }^{1}$, Philippe Kowalski ${ }^{2}$, Jimmy Leclair de Bellevue ${ }^{1}$, Nicolas Marquestaut ${ }^{9}$, \\ Dominique Mékies $^{1}$, Jean-Marc Metzger ${ }^{9}$, Joris Pianezze ${ }^{1}$, Thierry Portafaix ${ }^{1}$, Jean Sciare ${ }^{10}$, Arnaud Tournigand ${ }^{8}$, \\ and Nicolas Villeneuve ${ }^{2}$ \\ ${ }^{1}$ LACy, Laboratoire de l'Atmosphère et des Cyclones, UMR8105 CNRS, Université de La Réunion, Météo-France, \\ Saint-Denis de La Réunion, France \\ ${ }^{2}$ OVPF, Institut de Physique du Globe de Paris, UMR7154, CNRS, Université Sorbonne Paris-Cité, Université Paris Diderot, \\ Bourg-Murat, La Réunion, France \\ ${ }^{3}$ LaMP, Laboratoire de Météorologie Physique, UMR6016, CNRS, Université Blaise Pascal, Clermont-Ferrand, France \\ ${ }^{4}$ CNRM, Centre National de la Recherche Météorologique, UMR3589, CNRS, Météo-France, Toulouse, France \\ ${ }^{5}$ DESS, Department of Earth and Space Sciences, Chalmers University of Technology, Gothenburg, Sweden \\ ${ }^{6}$ Dipartimento DiSTeM, Universitá di Palermo, Italy \\ ${ }^{7}$ INGV, Istituto Nazionale di Geofisica e Vulcanologia, Sezione di Palermo, Italy \\ ${ }^{8}$ ORA, Observatoire Réunionais de l'Air, Saint-Denis de La Réunion, France \\ ${ }^{9}$ OSU-R, Observatoire des Sciences de l’Univers de la Réunion, UMS3365 CNRS, Université de La Réunion, \\ Saint-Denis de La Réunion, France \\ ${ }^{10}$ Energy, Environment, Water, Research Center, The Cyprus Institute, Nicosia, Cyprus
}

Correspondence to: Pierre Tulet (pierre.tulet@univ-reunion.fr)

Received: 29 September 2016 - Discussion started: 22 November 2016

Revised: 28 February 2017 - Accepted: 23 March 2017 - Published: 25 April 2017

\begin{abstract}
The STRAP (Synergie Transdisciplinaire pour Répondre aux Aléas liés aux Panaches volcaniques) campaign was conducted over the entire year of 2015 to investigate the volcanic plumes of Piton de La Fournaise (La Réunion, France). For the first time, measurements at the local (near the vent) and at the regional scales were conducted around the island. The STRAP 2015 campaign has become possible thanks to strong cross-disciplinary collaboration between volcanologists and meteorologists. The main observations during four eruptive periods ( 85 days) are summarised. They include the estimates of $\mathrm{SO}_{2}, \mathrm{CO}_{2}$ and $\mathrm{H}_{2} \mathrm{O}$ emissions, the altitude of the plume at the vent and over different areas of La Réunion Island, the evolution of the $\mathrm{SO}_{2}$ concentration, the aerosol size distribution and the aerosol extinction profile. A climatology of the volcanic plume dispersion is
\end{abstract}

also reported. Simulations and measurements show that the plumes formed by weak eruptions have a stronger interaction with the surface of the island. Strong $\mathrm{SO}_{2}$ mixing ratio and particle concentrations above $1000 \mathrm{ppb}$ and $50000 \mathrm{~cm}^{-3} \mathrm{re}-$ spectively are frequently measured over a distance of $20 \mathrm{~km}$ from Piton de la Fournaise. The measured aerosol size distribution shows the predominance of small particles in the volcanic plume. Several cases of strong nucleation of sulfuric acid have been observed within the plume and at the distal site of the Maïdo observatory. The STRAP 2015 campaign provides a unique set of multi-disciplinary data that can now be used by modellers to improve the numerical parameterisations of the physical and chemical evolution of the volcanic plumes. 


\section{Introduction}

The 2010 eruption of Eyjafjalläjökull (Iceland) showed how a relatively small volcanic event can directly impact the life of millions of people. Volcanic plumes can cause environmental, economic and societal impacts, and better knowledge of their physics, chemistry and time evolution are of paramount importance to improving the quality of our predictions and forecasts. Improving our ability to quantify and model the genesis, dispersion and impact of a volcanic plume is thus a key challenge for scientists and societal stakeholders. Furthermore, mitigation of volcanic crises relies on efficient and effective communication and interaction between multidisciplinary scientific actors in geology, physics, chemistry and remote sensing. The ultimate goal of the multidisciplinary approach is to couple a precise and real-time quantification of the volcanic source terms with accurate and fast modelling of physical and chemical processes to predict the ascent, dispersion and impact of volcanic plumes. The Eyjafjällajökull eruption has demonstrated, in an emblematic way, the challenges of forecasting the temporal evolution of volcanic source parameters for volcanic plumes, as well as of accurately assessing the ash and gas content, composition and size distribution of the drifting mass (Kaminski et al., 2011; Bursik et al., 2012; Folch et al., 2012). One major source of uncertainty is the lack of accurate measurements of basic and essential parameters, such as plume height and mass discharge rate (Ripepe et al., 2013).

The models also still need major improvements if we aim to adequately take into account the complexity and rapidly changing dynamics of a volcanic cloud. The improvement of our understanding of processes controlling the formation and evolution of volcanic clouds will represent a major step forward for the scientific community, as well as for sociopolitical stakeholders. Volcanic emission is also an important factor for climate change due to the enhancement of albedo by volcanogenic sulfates, among other things. In spite of its importance, the rate of $\mathrm{SO}_{2}$ degassing remains a poorly constrained source of sulfate particles through nucleation and/or condensation on pre-existing aerosol (Robock, 2000; Mather et al., 2005; Rose et al., 2006; Martin et al., 2008). Aerosols, in general, play an important role in the radiative budget both by scattering and absorbing radiation and by modifying the cloud microphysics, including their radiative properties and lifetime (Hobbs et al., 1982; Albrecht, 1989; Stevens et al., 1998; Ackerman et al., 2004; Sandu et al., 2009). The volcanic contribution of cloud condensation nuclei $(\mathrm{CCN})$ or ice-forming nuclei (IFN) through gas-to-particle conversion is estimated to $5-10 \mathrm{Tg} \mathrm{y}^{-1}$ (Halmer et al., 2002). This source is comparable to the biogenic sulfides $\left(25 \mathrm{Tg} \mathrm{y}^{-1}\right)$ and anthropogenic $\mathrm{SO}_{2}\left(79 \mathrm{Tg} \mathrm{y}^{-1}\right)$ contributions (Penner et al., 2001). Recently, Ebmeier et al. (2014) have shown that passive degassing and weak eruptions increase the aerosol optical depth and decrease the average cloud droplet effective radius downwind of the eruptive vent. For all these rea- sons, the atmospheric science community is now focused on a better estimate of the volcanic source of CCN and IFN for climate models. The achievement of these goals requires (i) the improvement of the quantification of volcanic degassing (mainly $\mathrm{H}_{2} \mathrm{O}, \mathrm{CO}_{2}$ and $\mathrm{SO}_{2}$ ) during and between eruptions, and (ii) the parameterisation of the aerosols nucleation inside volcanic plumes presenting specific conditions of temperature, humidity and concentration. High-frequency quantification of gas emissions during weak to moderate volcanic events can be achieved by the integration of multiple ground-based techniques (e.g. DOAS, MultiGAS, FTIR) (Conde et al., 2014, and references therein). Specifically, this approach permits us to track gas emissions with a high spatial and temporal resolution and to take into account the strong atmospheric background of some of them (e.g. $\mathrm{CO}_{2}, \mathrm{H}_{2} \mathrm{O}$ ). Concerning aerosols, Boulon et al. (2011) provided the first observational evidence of the occurrence of aerosol nucleation within a volcanic plume. These authors demonstrated that the classical binary nucleation scheme $\left(\mathrm{H}_{2} \mathrm{SO}_{4}-\mathrm{H}_{2} \mathrm{O}\right)$ used in meteorological models underestimates the observed particle formation rates in volcanic plumes by 7 to 8 orders of magnitude. These preliminary results suggest that nucleation schemes for volcanic plumes must be revised.

In this context, the French National Research Agency has funded the transdisciplinary programme named STRAP (Stratégie Transdisciplinaire pour Répondre aux Aléas liés aux Panaches Volcaniques) for the period 2014-2019. The objectives of the STRAP experiment were to perform the tracking and sounding of volcanic plumes with the aim of integrating complex physico-chemical processes governing their temporal and spatial evolution. The programme traces volcanic plumes from their source (high temperature, concentrated) to the regional scale during their dispersion and deposition. The STRAP experiment is based on two observation periods in 2015 (Piton de la Fournaise, France) and 2016 (Etna, Italy). The 2015 STRAP experiment has been performed on the Piton de la Fournaise (PdF) volcano and has benefited of a strong cross-disciplinary collaboration between European scientists from 10 laboratories (France, Italy, Sweden, Cyprus). Piton de la Fournaise was selected as it is a well-known, very active volcano (four eruptions in 2015) and emits lava flows and gas plumes carrying negligible amounts of ash (Roult et al., 2012; Michon et al., 2013). Very few data exist on the composition and fluxes of high-temperature volcanic gases emitted by PdF eruptions (see Di Muro et al. (2016a) for a recent review). The gas plumes of PdF have been targeted to (i) estimate the dayby-day emission rates of $\mathrm{SO}_{2}, \mathrm{H}_{2} \mathrm{O}$ and $\mathrm{CO}_{2}$, (ii) measure and model the altitude and direction of buoyant plume above the source area, (iii) quantify the formation of new particles to improve the parameterisation of nucleation in the models, and (iv) study and model the transport, ageing, dry and wet deposition of the volcanic plumes around La Réunion island. The purpose of this paper is twofold: (i) to present the methodological approach developed for the first time on this 
volcano to track the Piton de la Fournaise plume from the source to the distal area, and (ii) to summarise the preliminary quantification of gaseous emission budget, plume location, height and dispersion as well as gas-particle conversion.

\section{Description of the 2015 STRAP campaign on Piton de la Fournaise}

\subsection{Topography and climate of La Réunion island}

La Réunion $\left(21^{\circ} \mathrm{S}, 55^{\circ} \mathrm{E}\right)$ is a volcanic island located in the south-western part of the Indian Ocean. The topography of La Réunion island is complex, with deep valleys, steep slopes and high peaks. Piton des Neiges, located in the north-central region of La Réunion, is the highest point on the island and reaches $3070 \mathrm{~m}$ a.s.l. (above sea level). Located in the southeastern sector of La Réunion Island, Piton de la Fournaise $(2631 \mathrm{~m})$ is one of the world's most active volcanoes (Michon et al., 2015). Three cirques (Salazie, Mafate and Cilaos) surround the peak of Piton de Neiges (Fig. 1). They have been formed by old volcanic activity which collapsed a once tall volcanic edifice and were then scoured out by intense erosion (Lenat, 2016). La Réunion benefits from a tropical climate under the influence of sea breezes and night katabatic flow in the valleys. The island is affected by south-easterly trade winds near the ground and westerlies in the free troposphere (Lesouëf et al., 2011). The eastern and western parts of the island are wet and dry respectively. Clouds develop daily on the summits and on the flanks of the island, with a well-established diurnal cycle (formation in the late morning, dissipation at the end of the afternoon or at the beginning of the night). Durand et al. (2014) have shown that air quality during volcanic eruptions is strongly dependent on mesoscale atmospheric circulation on La Réunion Island.

\subsection{Geological context of Piton de la Fournaise}

Piton de la Fournaise is a very active intraplate basaltic volcano, the youngest tip of the $5000 \mathrm{~km}$-long hotspot chain that fed the Deccan Trap flood basalt $65 \mathrm{M}$ years ago (e.g. Duncan, 1981). About $97 \%$ of the recent eruptive activity occurred in the 5465-2971-year-old Enclos Fouqué caldera (Fig. 1), an approximately $8.5 \times 13 \mathrm{~km}^{2}$-wide structure, which is an uninhabited seaward open natural depression (Villeneuve and Bachèlery, 2006; Michon et al., 2015; Ort et al., 2016). This intracaldera activity has contributed to the formation of the $400 \mathrm{~m}$ high summit cone with a top consisting of two depressions, the Dolomieu caldeira and the Bory crater, to the east and west respectively. According to the location of the eruptive fissures, three types of eruptions have been defined (Peltier et al., 2009): (i) summit eruptions located at the volcano summit, (ii) proximal eruptions located on the flank of the summit cone (Michon et al., 2007, 2015; Bonali et al., 2010) and (iii) distal eruptions located outside of the summit cone. According to this classification, (a)

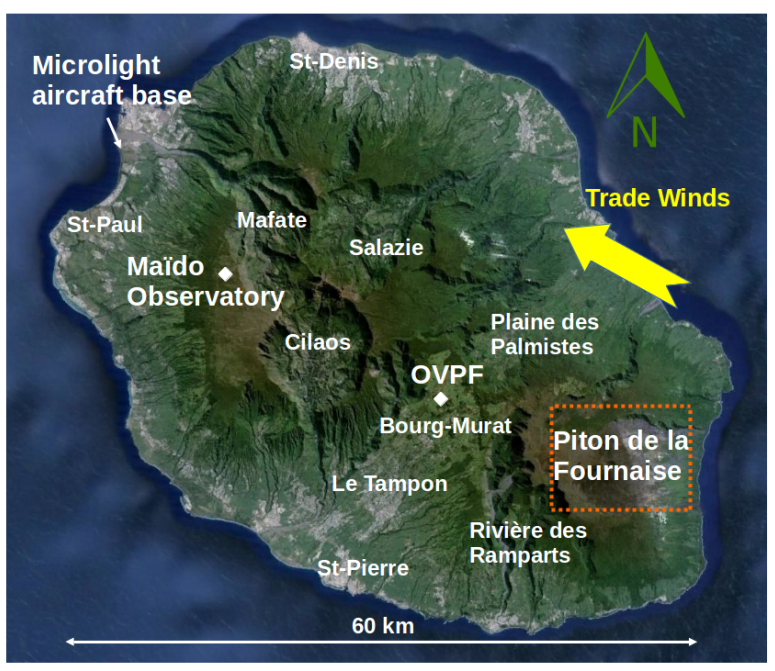

(b)

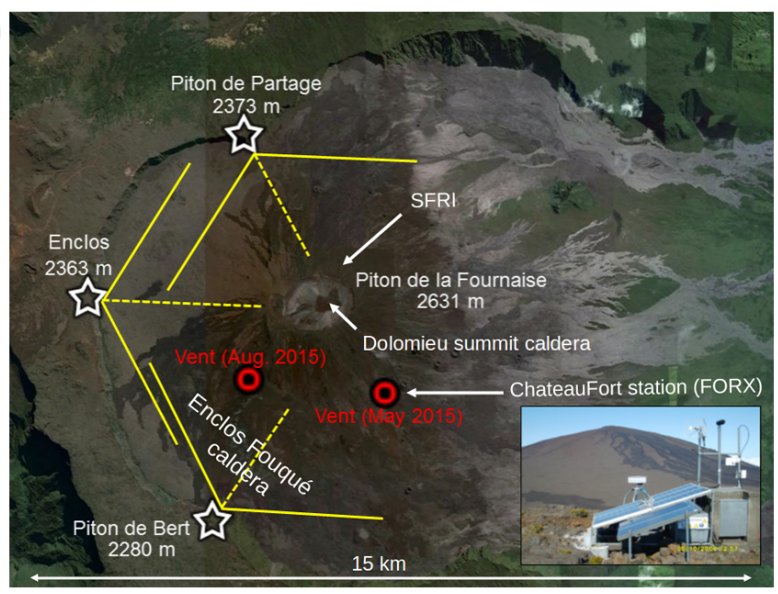

Figure 1. (a) Map of La Réunion island including the sites of interest quoted in the text: the locations of the principal cities, the Piton de La Fournaise volcano and the three major sites of the campaign (white). The yellow arrow indicates the mean direction of the trade winds and the dotted rectangle represents the area shown in the bottom panel. (b) Location of the scanning-DOAS stations of the NOVAC/OVPF network (stars; the picture shows the Enclos station). The dashed lines are the azimuths of the main axis for each station and the continuous lines the angular coverage of each scanner. The locations of the main eruptive vents of the May and AugustOctober 2015 eruptions are also shown (concentric dots).

eruptions studied in May and August 2015 by the STRAP teams are classified as proximal (Fig. 1). Over the last few decades, the degassing of Piton de la Fournaise was negligible outside the eruption periods (Di Muro et al., 2016b).

\subsection{Recent historical activity of Piton de la Fournaise}

During the 1998-2010 period of sustained activity, the Piton de la Fournaise volcano produced 2.6 eruptions per year, on average, spanning a large range of emitted volume of lava, between $<1$ and $210 \mathrm{M} \mathrm{m}^{3}$ (Peltier et al., 2009; Stau- 
dacher et al., 2009; Roult et al., 2012). Even if phreatic and phreatomagmatic eruptions have been described in the 18th and 19th centuries (Peltier et al., 2012; Michon et al., 2013), since the end of the 18th century the eruptive activity has mostly consisted of dominantly effusive or weakly explosive eruptions. A characteristic of Piton de la Fournaise eruptions consists of the opening of en echelon fissures, with an activity rapidly declining in intensity and focusing on the lowest point of the feeding fissure and forming a small cone from the accumulation of ejecta (Hibert et al., 2015). The main erupted volume is represented by the lava flows (Michon et al., 2015). The associated volcanic plumes are often loaded with little ash. The last major ash emissions occurred during the major caldera forming April 2007 event, when the Dolomieu summit caldera collapsed (Staudacher and Peltier, 2015). In 2007, a major pulse of deep magma triggered the expulsion of $210 \mathrm{M} \mathrm{m}^{3}$ of magma mostly stored in the shallow part of the volcano plumbing system. It provoked the collapse of the Dolomieu summit caldera to a depth of $320 \mathrm{~m}$ (Staudacher et al., 2009; Di Muro et al., 2014). During this major historical eruption, a total $\mathrm{SO}_{2}$ mass of $230 \mathrm{kt}$ was released, of which about $60 \mathrm{kt}$ were transformed into $\mathrm{H}_{2} \mathrm{SO}_{4}$, while $27 \mathrm{kt}$ of $\mathrm{SO}_{2}$ and $21 \mathrm{kt}$ of $\mathrm{H}_{2} \mathrm{SO}_{4}$ were deposited at the surface by dry deposition (Tulet and Villeneuve, 2011). During the shortest-lived eruptions, lava and gas emission rates are linearly correlated and both decline quickly after an initial intense phase (Hibert et al., 2015). Periods of intense eruptive activity (e.g. 19721992, 1998-2010, mid-2014-today) alternate with relatively long periods of rest (e.g. 1966-1972, 1992-1998, 2011-mid2014; (Peltier et al., 2009; Roult et al., 2012). From 2007 to 2010 , the volcanic activity was relatively weak, with several short lived, small volume eruptions and intrusions mostly located close to the central cone (Peltier et al., 2010; Roult et al., 2012; Staudacher et al., 2015). It was followed by a relatively long phase of quiescence of 41 months (February 2011-June 2014) before a fast reawakening in June 2014 (Peltier et al., 2016). During the phase of quiescence, the volcano deflated. Daily micro-seismicity was limited to a few shallow volcano-tectonic events, and summit intracaldera fumaroles emitted low-temperature $S$ - and $\mathrm{CO}_{2}$-poor watervapour-dominated fluids (Di Muro et al., 2016a). In 20142015, the OVPF recorded an increasing rate of activity in terms of deformation, seismicity, gas emissions and eruption rate, culminating in five eruptions (Peltier et al., 2016).

\subsection{Description of the eruptions during the 2015 STRAP campaign}

Like most eruptions of the recent historical activity, they all occurred inside the Enclos Fouqué caldera (Fig. 1). This last sequence of eruptions showed a progressive increase in the output rates (Coppola et al., 2017). The different eruptive event, located with respect to the central cone of PdF, include 4-15 February 2015 (west-south- west; $1.5 \pm 0.2 \mathrm{M} \mathrm{m}^{3}$ of erupted products), 17-30 May 2015 (south-south-east; $4.6 \pm 0.6 \mathrm{M} \mathrm{m}^{3}$ of erupted products), 31 July-2 August 2015 (north; $2 \pm 0.3 \mathrm{M} \mathrm{m}^{3}$ of erupted products) and 24 August-31 October 2015 (west-south-west; $35.7 \pm 3 \mathrm{M} \mathrm{m}^{3}$ of erupted products in three successive stages: 24 August-18 October, 22-24 October and 29-31 October). The renewal of eruptive activity in 2015 was associated with long-term continuous edifice inflation measured by GNSS (global navigation satellite system). The time evolution of monitoring parameters has revealed that the volcano reawakening was associated with continuous pressurisation of the shallowest parts of its plumbing system, triggered by progressive upwards transfer of magma from a greater depth (Peltier et al., 2016). Coppola et al. (2017) conclude that, in 2015 , both a pulse in deep refilling, as well as perturbation of the hydrothermal system and the weakening of the edifice's strength, would have favoured the occurrence of frequent and increasingly large eruptive activity at Piton de la Fournaise, leading to reservoir rejuvenation.

\section{Methods, models and measurements}

\subsection{STRAP campaign management}

The Observatoire Volcanologique du Piton de la Fournaise (OVPF/IPGP) manages the monitoring networks on the island, allowing the observatory to follow eruptive and specific volcanic events and to describe their time and space evolution. In the frame of the STRAP programme, the OVPF, NOVAC (Network for Observation of Volcanic and Atmospheric Change, Chalmers University) and INGV (Istituto Nazionale di Geofisica e Vulcanologia) teams were in charge of the quantification of volcanic gas emissions close to the vent and the sampling of solid products. OVPF has implemented four permanent ground-based networks: (i) imagery, (ii) seismological, (iii) geodetical and (iv) geochemical. Multispectral satellite imagery and ground-based and drone visible and thermal imagery complement these data sets. The Observatoire de Physique de l'Atmosphère de la Réunion (OPAR) coordinated the observations of volcanic plumes at regional scale across the island. During the STRAP campaign, the OPAR has coordinated different laboratories specialised in atmospheric science. The Maïdo atmospheric observatory (Baray et al., 2013) located at $2200 \mathrm{~m}$ altitude and at $43 \mathrm{~km}$ north-west of the Piton de La Fournaise (Fig. 1) is the main observation site of the OPAR. From the air base of SaintPaul, the OPAR has operated an ultralight aircraft equipped with on-board instruments to measure the $\mathrm{SO}_{2}$ molar concentration, the particle number and the size distribution of aerosols. In addition, a mobile aerosol lidar was installed on a pick-up truck to study the altitude, thickness and optical properties of the volcanic plumes (Fig. 1). The ORA (Observatoire Réunionnais de l'Air) has also participated through their air quality network on La Réunion island. 


\subsection{Flexpart modelling}

The Flexfire forecasting tool is based on the coupling between the FLEXPART Lagrangian particle dispersion model (Stohl et al., 2005) and the AROME mesoscale weather forecasting model (Seity et al., 2011). To calculate Lagrangian trajectories, we used version 9 of the FLEXPART model modified to be coupled with AROME output. In the AROME forecast outputs, 3-D fields of meteorological parameters such as wind, humidity and temperature are available on 12 Cartesian vertical levels up to $3000 \mathrm{~m}$ altitude and on a dozen pressure levels up to $100 \mathrm{hPa}$. The vertical levels from AROME were used as the 12 first vertical levels following the vertical grid of the FLEXPART model. For altitudes higher than $3000 \mathrm{~m}$ a.g.l., a vertical interpolation was performed to project the AROME pressure levels onto the FLEXPART vertical coordinates. The Hanna turbulent scheme (Hanna, 1982) was used to represent turbulent mixing in the boundary layer. In order to run the model with an accurate representation of the turbulent mixing in the planetary boundary layer, the time step in FLEXPART is calculated depending on the values of a Lagrangian timescale, vertical velocity and mixing height at each trajectory position. An upper limit was fixed at $180 \mathrm{~s}$ for horizontal mixing and $36 \mathrm{~s}$ for vertical mixing. Since the Eulerian meteorological fields were available at $0.025^{\circ} \times 0.025^{\circ}$ resolution, the mesoscale meandering term in the FLEXPART model was removed. A tracer emitted at the vent was used in the FLEXPART simulation to represent the transport and dispersion of the volcanic $\mathrm{SO}_{2}$. To avoid biases due to uncertainties in the precipitation field from AROME, this tracer has been introduced as passive (i.e. without rain scavenging). During the field campaign, forward FLEXPART trajectories were simulated over $36 \mathrm{~h}$ using the AROME forecasts. Each trajectory carried an equal mass of a passive tracer based on an arbitrary surface flux. Overall, 40000 trajectories were released per FLEXPART forecast. These forecasts were used day-byday to manage the strategy of the STRAP observations (e.g. ultralight aircraft flight plan, lidar location, portable DOAS measurements).

\subsection{Measurements near the plume source}

In the framework of the STRAP project, permanent scanning and mobile remote DOAS measurements of the $\mathrm{SO}_{2}$ mass emission rate, in situ MultiGAS measurements of the molar concentrations of $\mathrm{H}_{2} \mathrm{O}, \mathrm{CO}_{2}, \mathrm{H}_{2} \mathrm{~S}$ and $\mathrm{SO}_{2}$ (Table 1) and rock sampling (Appendix Table A1) were performed. In the proximal area, close to the eruptive vents, regular surveys and visible and thermal imagery have allowed us to follow the time and space evolution of eruptive dynamics and to constrain the evolution of the degassing source. The temporal and spatial evolution of lava emissions were constrained by detailed mapping of the lava field combined with satellite imagery (Coppola et al., 2017). The gas geochemi- cal network of OVPF groups three techniques: DOAS (differential optical absorption spectroscopy), MultiGAS (multicomponent gas analyzer system) and diffuse $\mathrm{CO}_{2}$ soil flux. Gas data interpretation is constrained by the geochemical and petrological analysis of the composition of the eruptive products (naturally or water quenched), performed at LMV (Laboratoire Magmas et Volcans) and IPGP (Di Muro et al., 2016b). Time series analysis of gas geochemical data are correlated with geophysical (seismicity, deformation) data series to assess the time and space evolution of the eruptions, the dynamics of the magma and fluids storage zone(s) and to put constraints on their volume and pressure (depth), as well as to make inferences on the rate and timing of magma and fluid transfer and accumulation at depth (Coppola et al., 2017). The output budget of the main components of the vent gas emissions has been quantified by integrating the $\mathrm{SO}_{2}$ fluxes (DOAS) with the ratios of the main species $\left(\mathrm{H}_{2} \mathrm{O} / \mathrm{SO}_{2}, \mathrm{CO}_{2} / \mathrm{SO}_{2}\right)$, measured in situ close to the eruptive vent by portable MultiGAS. The three permanent scanning DOAS stations of OVPF (Partage in the north, Enclos in the west, Bert in the south) are installed close to the rim of Enclos Fouqué caldera (Fig. 1) and have worked continuously during the 2015 eruptions. Details of the instrument and evaluation procedure are given in Galle et al. (2010). The three stations have acquired up to 115 scans of the plume every day (on average 34 scans every day or one complete plume scan per $13 \mathrm{~min}$ ), which allow for the estimation of $\mathrm{SO}_{2}$ column density, plume height and dispersion direction and quantification of the total $\mathrm{SO}_{2}$ emission rate. Individual DOAS scan measurements were validated by selecting only completely sampled plumes. Under this geometrical condition, the plume is well elevated above the ground level and its transport corresponds to a given range of wind directions for each station. Poor quality data sets were acquired on 13 September and 3 October due to rainy conditions. Transects of the plume were periodically acquired by portable DOAS in order to validate data acquired by portable stations or to guarantee a better coverage of unusual plume geometries. Portable DOAS data have been treated following the Salerno et al. (2009) procedure. For DOAS data sets, $\mathrm{SO}_{2}$ fluxes have been obtained by integrating the column densities across the plume cross section and scaling with wind speed data kindly provided by the Météo-France station located at Bellecombe, in between the Partage and Enclos stations. Wind data are acquired hourly and on a mast at $10 \mathrm{~m}$ a.g.l. The plume height and direction were obtained by triangulation from the scans of two DOAS stations (Galle et al., 2010). Lava output rates have been estimated on the basis of $\mathrm{SO}_{2}$ fluxes using the Hibert et al. (2015) approach, which has been calibrated on the low-intensity January 2010 eruption. This procedure requires some assumptions of the pre-eruptive magma $S$ content, $S$ speciation and phase partitioning, as well as on the density of the emitted lava. This approach is clearly an oversimplification of a complex long-lasting eruption like that of August 2010. 
Table 1. Summary of in situ chemical measurements (MultiGAS, portable mini-DOAS and FLIR camera) made on field near the vent on May-October 2015. The symbol "X" indicates when measurements using FLIR camera have been done.

\begin{tabular}{|c|c|c|c|}
\hline $\begin{array}{l}\text { Date } \\
(\mathrm{MM} / \mathrm{DD} / \mathrm{YY})\end{array}$ & $\begin{array}{l}\text { MultiGAS } \\
\text { local time; coordinates }\end{array}$ & $\begin{array}{l}\text { Portable mini-DOAS } \\
\text { local time, location }\end{array}$ & $\begin{array}{l}\text { Portable } \\
\text { FLIR camera }\end{array}$ \\
\hline $5 / 17 / 2015$ & 16:00-16:24; (close to lava field; $\left.21^{\circ} 15^{\prime} 58.9^{\prime \prime} \mathrm{S}, 55^{\circ} 42^{\prime} 59.8^{\prime \prime} \mathrm{E}\right)$ ) & - & $\mathrm{X}$ \\
\hline $5 / 18 / 2015$ & 13:45-14:06; (near eruptive vent; $\left.21^{\circ} 15^{\prime} 26.0^{\prime \prime} \mathrm{S}, 55^{\circ} 43^{\prime} 28.4^{\prime \prime} \mathrm{E}\right)$ & 12:01, GPS Track & - \\
\hline $5 / 19 / 2015$ & 13:26-13:41; helicopter near eruptive vent & 13:25, GPS Track & $\mathrm{X}$ \\
\hline $5 / 20 / 2015$ & $15: 15-15: 41$; near eruptive vent & - & $\mathrm{X}$ \\
\hline $5 / 21 / 2015$ & & 10:26, GPS Track & - \\
\hline $5 / 24 / 2015$ & 12:22-12:50; near eruptive vent & - & - \\
\hline $8 / 24 / 2015$ & & - & $\mathrm{X}$ \\
\hline $8 / 25 / 2015$ & $11: 42-12: 12 ;\left(21^{\circ} 15^{\prime} 19.1^{\prime \prime} \mathrm{S}, 55^{\circ} 42^{\prime} 14.9^{\prime \prime} \mathrm{E}\right)$ & $\begin{array}{l}\text { 10:20, GPS Track } \\
\text { Plaine des Sables }\end{array}$ & - \\
\hline $8 / 27 / 2015$ & & - & $\mathrm{X}$ \\
\hline $8 / 27 / 2015$ & $12: 22-12: 40 ;\left(21^{\circ} 15^{\prime} 19.1^{\prime \prime} \mathrm{S}, 55^{\circ} 42^{\prime} 14.9^{\prime \prime} \mathrm{E}\right)$ & - & - \\
\hline $8 / 27 / 2015$ & $\begin{array}{l}10: 25-10: 45 ; \text { (close to the vent exit and along the lava channel: } \\
21^{\circ} 15^{\prime} 24.2^{\prime \prime} \mathrm{S}, 55^{\circ} 42^{\prime} 15.9^{\prime \prime} \mathrm{E} \text { to } 21^{\circ} 15^{\prime} 31.2^{\prime \prime} \mathrm{S}, 55^{\circ} 42^{\prime} 11.7^{\prime \prime} \mathrm{E}\end{array}$ & - & - \\
\hline $8 / 28 / 2015$ & 14:20 (Plaine des Sables) & - & - \\
\hline $9 / 01 / 2015$ & & - & $\mathrm{X}$ \\
\hline $9 / 03 / 2015$ & & - & $\mathrm{X}$ \\
\hline 9/03/2015 & $11: 45-12: 45$; close to active eruptive fissure & - & - \\
\hline 09/07/2015 & $12: 15-13: 00$; close to active eruptive fissure & 12:22, GPS Track & - \\
\hline 09/08/2015 & & - & $\mathrm{X}$ \\
\hline $09 / 11 / 2015$ & & - & $\mathrm{X}$ \\
\hline $09 / 11 / 2015$ & $11-12: 36$; close to the only active cone & 11:17, GPS Track & - \\
\hline $09 / 15 / 2015$ & $16: 30-17: 05$; close to the only active cone & - & $\mathrm{X}$ \\
\hline 09/18/2015 & $12: 00-13: 24$; close to the only active cone & 12:22, GPS Track & $\mathrm{X}$ \\
\hline $10 / 07 / 2015$ & $11: 00-11: 30$; close to the only active cone & - & - \\
\hline $10 / 09 / 2015$ & & - & $\mathrm{X}$ \\
\hline $10 / 11 / 2015$ & & - & $\mathrm{X}$ \\
\hline 10/16/2015 & & - & $X$ \\
\hline $10 / 22 / 2015$ & & - & $\mathrm{X}$ \\
\hline $10 / 23 / 2015$ & $12: 40-13: 34 ;$ close to the only active cone & - & $\mathrm{X}$ \\
\hline $10 / 26 / 2015$ & $08: 30-09: 04$; on the rim of the active crater during the rest phase $(26 / 10)$ & - & $\mathrm{X}$ \\
\hline \multirow[t]{2}{*}{ 10/30/2015 } & 10:37 (Plaine des Sables) & 10:37, GPS Track & - \\
\hline & 11:37 (Plaine des Sables) & 11:37, GPS Track & - \\
\hline $10 / 31 / 2015$ & $15: 37-15: 56$; close to the feeding outbreak of the new lava outburst & - & - \\
\hline
\end{tabular}

For instance, magma chemical zoning potentially translates to highly changing initial $\mathrm{SO}_{2}$ contents and can produce a high error in the estimate. In situ analysis of gas emissions have been performed using a mobile MultiGAS device ( 5 sets of measurements in May and 12 in August-October) during both eruptions targeted by the STRAP project. A MultiGAS portable station has been installed or carried downwind and close to the eruptive vent (at a distance of tens to hundreds of metres from the degassing sources) for acquisition times of $15-96 \mathrm{~min}$ ( $0.1 \mathrm{~Hz}$ sampling rate). On 19 May the measurements were performed from a helicopter during a flight close to the main high-temperature degassing source. The purpose of the experiment was to measure the relative molar concentration of the main components of the gas phase emitted by several sources (eruptive vent, fumaroles and lavas). The MultiGAS device integrates a dual beam IR spectrometer $\left(\mathrm{CO}_{2}\right)$, electrochemical sensors $\left(\mathrm{H}_{2} \mathrm{~S}\right.$ and $\left.\mathrm{SO}_{2}\right)$, a hygrom- eter, and pressure and temperature sensors. A more complete description of the MultiGAS system used in our experiments can be found in Aiuppa et al. (2009). Water vapour content is recalculated from hygrometric measurements. Subtraction of the atmospheric background permits the quantification of the elemental molar ratios (e.g. $\mathrm{H}_{2} \mathrm{O} / \mathrm{SO}_{2}, \mathrm{CO}_{2} / \mathrm{SO}_{2}$ molar ratios) in the volcanic emissions. Here, correlation of these ratios with the $\mathrm{SO}_{2}$ fluxes $(4.8 \pm 1.1 \mathrm{kt}$ in May and $33.8 \pm 7.4 \mathrm{kt}$ in August; Coppola et al., 2017) measured by DOAS permit a first estimation of the syn-eruptive fluxes of $\mathrm{H}_{2} \mathrm{O}$ and $\mathrm{CO}_{2}$ released by the eruptive vent(s). In May and August 2015, the OVPF team sampled 10 and 50 rock samples for geochemical analyses respectively (Table A1). Bulk rock, crystal and melt inclusion composition are under study to constrain the pre-eruptive storage conditions of the magma (pressure, temperature, gas content and composition) and to identify the possible involvement of several magma sources. 


\subsection{Measurements of the physical and chemical properties of the plume}

At the Maïdo observatory, gases such as $\mathrm{SO}_{2}, \mathrm{NO}_{x}, \mathrm{CO}$, $\mathrm{O}_{3}$, the size distribution and the extinction of aerosols, and the CCN (cloud condensation nuclei) size distribution are measured continuously. A proxy of the sulfuric acid concentration was calculated from the concentration of $\mathrm{SO}_{2}$ and radiation measured with a pyranometer. During the 2015 STRAP campaign, an AIS (air ion spectrometer) and a nano CPC (condensation particle counter) have been added to estimate the aerosol nucleation. The size distribution of the $10-500 \mathrm{~nm}$ aerosol particles were measured with a differential mobility particle sizer (DMPS) while the $0.8-42 \mathrm{~nm}$ size distribution of the naturally charged fraction of aerosols were measured with the AIS. The AIS is developed by Airel Ltd (Estonia), for in situ high time resolution measurements of ions and charged particles (Mäkelä et al., 1996). In the STRAP campaign we use ion size distributions below $10 \mathrm{~nm}$ as tracers for the presence of neutral sub-10 nm particles which could not be directly detected. The DMPS is custombuilt with a TSI-type differential mobility analyser (DMA) operating in closed loop and a condensation particle counter (CPC, TSI model 3010). The quality of the DMPS measurements was checked for flow rates and relative humidity according to the ACTRIS (Aerosols, Clouds, and Trace gases Research InfraStructure Network) recommendations (Wiedensohler et al., 2012). DMPS measurements were performed down a whole air inlet of a higher size cut of $25 \mu \mathrm{m}$ (under average wind speed conditions of $4 \mathrm{~m} \mathrm{~s}^{-1}$ ). The device consists of two DMA arranged in parallel which allow for the simultaneous measurement of both negatively and positively charged particles (Gagné et al., 2011). The AIS was directly connected to ambient air through a $30 \mathrm{~cm}$ copper tubing of $2.5 \mathrm{~cm}$ in diameter in order to limit cluster ion losses along the sampling line. The AIS measurements allow for the calculation of the growth rate (Hirsikko et al., 2007) of newly formed particle. Both instruments operated simultaneously over the three eruptive periods from 9 May to 18 October 2015 (Fig. 2), together with $\mathrm{SO}_{2}$ measurements operated by ORA (model Thermo Scientific 43i). A mobile aerosol lidar in synergy with a handheld sun photometer has been installed on a truck coupled with a set of batteries. This flexible system enabled us to move under the aerosol plume in order to measure the aerosol optical properties, the thickness and the horizontal extension of the plume. The area of the truck measurement and the flight trajectory were planned every day during a briefing using forecasts from the French Meteorological Office (DIROI / Météo-France) and FLEXPART simulations of the dispersion of the volcanic plume. The lidar system used in this study is a LEOSPHERE ${ }^{\circledR}$ ALS450 based on a Nd: Yag laser, producing pulses with a mean energy of $16 \mathrm{~mJ}$ at $355 \mathrm{~nm}$ and a frequency of $20 \mathrm{~Hz}$. Lidar measurements have been averaged over 2 min with a vertical resolution of $15 \mathrm{~m}$. The lidar profiles enable us to retrieve atmospheric structures (boundary layer heights, aerosol layers and clouds) and optical properties (lidar ratio, LR, and extinction coefficient profiles) in synergy with sun photometer measurements. Its full overlap height is reached at $150 \mathrm{~m}$ which makes it particularly well-adapted to planetary boundary layer (PBL) studies. For the STRAP campaign, the system was installed in an air conditioned box adapted for use in severe conditions. Depending on the FLEXPART forecast simulations, the lidar system was either set at a fixed position at the OVPF site in Bourg Murat $\left(21.12^{\circ} \mathrm{S}, 55.34^{\circ} \mathrm{E}\right.$; $1560 \mathrm{~m}$ a.s.l.), or attached on a pick-up truck platform to perform mobile observations of the volcanic plume. In this last case, the energy was supplied by six batteries connected to a power inverter, which gave approximately $3 \mathrm{~h}$ autonomy to the system. Aerosol optical thickness (AOT) measurements were performed in clear-sky conditions using a MICROTOPS II sun photometer instrument (Solar Light, Inc.). The instrument field of view is about $1^{\circ}$. The AOT is measured at five wavelengths $(440,500,675,870$ and $1020 \mathrm{~nm})$. The instrument was calibrated at the NASA Goddard Space Flight Center against the AERONET reference CIMEL sun/sky radiometer. The data presented here have been quality and cloud screened following the methodology of Smirnov et al. (2000) and Knobelspiesse et al. (2003) and the mean uncertainty of the AOT measurements equals 0.015 (Pietras et al., 2002). The AOT at the lidar wavelength of $355 \mathrm{~nm}$ $\left(\mathrm{AOT}_{355}\right)$ was calculated from $\mathrm{AOT}_{440}$ using the Angström exponent (Ångström, 1964) between 440 and $675 \mathrm{~nm}$. The uncertainty of the retrieved $\mathrm{AOT}_{355}$ has been computed following the approach showed by Hamonou et al. (1999). The synergetic approach between lidar and sun photometer measurements to calibrate the lidar system, retrieve aerosol optical properties and evaluate the uncertainties can be found in Duflot et al. (2011). It is noteworthy that this method gives access to a height-independent LR value. In our case, the contributions of the aerosols trapped in the PBL (sea salts, aerosols originating from anthropogenic activities such as fossil fuel combustion) and of the volcanic aerosols can not be set apart. The aerosol optical properties given hereafter are therefore valid for the encountered mixtures of aerosols. An ultralight aircraft equipped with on-board instruments permitted in situ measurements of the $\mathrm{SO}_{2}$ molar concentration, the particle number and size distribution of aerosols in the volcanic plume. The ultralight aircraft was located at the air base of Saint-Paul (Fig. 1). The operating range (1.5 h) of the instruments was sufficient to reach the area of the Piton de la Fournaise and to make several transects through the volcanic plume. The ultralight aircraft (FK9 ELA) equipped with on-board instruments conducted 18 flights from 19 May to 18 September 2015 over La Réunion. Details of the flights are compiled in Table 2. The eruptive events were probed extensively, including horizontal and vertical volcanic plume structures. The aircraft conducted measurements up to an altitude of $6 \mathrm{~km}$ a.s.l. and was equipped with a piston engine (ROTAX 912) that allowed it to fly inside the plume at a 


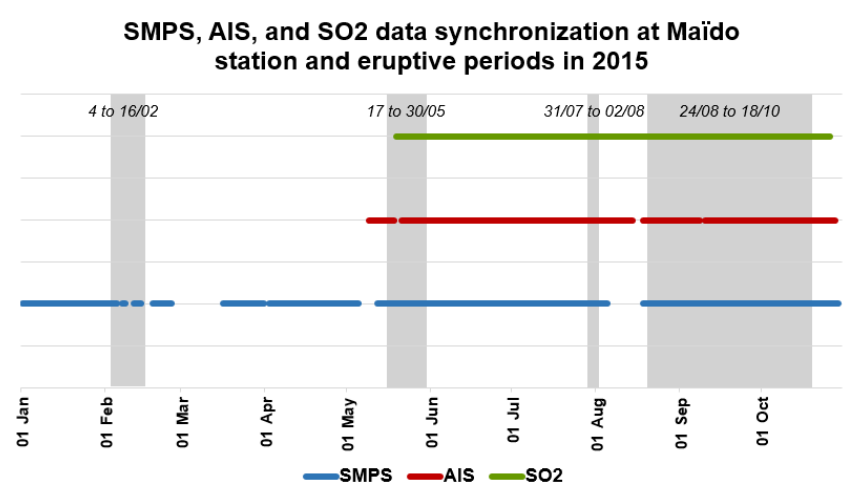

Figure 2. Data coverage of instrumentation for the characterisation of new particle formation events during the eruption periods (in grey) in 2015 .

minimum distance of $2 \mathrm{~km}$ from the eruption vent. The aircraft payload included meteorological sensors for temperature, pressure and relative humidity. Gas phase measurements of sulfur dioxide were made using a UV Fluorescence $\mathrm{SO}_{2}$ Analyzer (Teledyne, model T100U), which relies on pulsed fluorescence and has a detection limit of $50 \mathrm{ppt}$ (i.e. $0.05 \mathrm{ppb}$ ). During the campaign we chose a range of 0 $3000 \mathrm{ppb}$. The integrated number concentration of particles larger than $7 \mathrm{~nm}$ in diameter was measured using a butanolbased condensation particle counter (MCPC, Brechtel model 1720). A customised version of MetOne OPC (Profiler 212 without heater) was used to measure aerosol size distributions between $500 \mathrm{~nm}$ and $10 \mu \mathrm{m}$ in 8 size classes. The particle loaded air was fed through an isokinetic inlet into the CPC and the OPC. Data were recorded during the flights by a processor-based Mbed microprocessor board and stored on microSD card.

\section{Results}

\subsection{Simulation of the regional plume distribution in 2015}

After the field experiments, FLEXPART was rerun as a postprocessing tool with the aim of simulating the atmospheric transport during the eruptive events. The temporal mean of the tracer load was modelled for the two main eruptive events of May 2015 (14 days of simulation) and AugustOctober 2015 (70 days of simulation). Figures 3 and 4 show the probability of occurrence of the tracer load integrated over all model levels and normalised at 00:00, 06:00, 12:00 and 18:00 UTC (local time, LT, is UTC+4) respectively for the two main periods. The normalisation was performed for each hour during the simulation period by dividing the charge field of the tracer by the load modelled above the vent. In this way, the emission area is normalised to $1(100 \%$ of presence of the tracer plume above the vent). Thus, the field plotted in Figs. 3 and 4 also represents the percentage of dilution of the tracer load during the plume dispersion. During the May eruption period (Fig. 3), the tracer plume was highly dispersed due to an important variability of the wind field. The modelled diurnal evolution of the tracer load shows a strong influence of the evolution of the boundary layer and of the local circulation related to the topography close to the source area. At night and in the morning (18:00 to 06:00 UTC), the model forecasts local maxima of the tracer load to the west (Valley of the Rivière des Ramparts), to the north-west (Tampon-Bourg-Murat) and to the north (Plaine des Palmistes) of the vent (Fig. 1). These maxima reveal the potential occurrence of zones of strong $\mathrm{SO}_{2}$ accumulation at night-time formed by a downwind density current and generated by the difference in air density between the summit and the valleys. These results are consistent with visual observation from the ultralight aircraft, showing a bluish plume over the cirque of Cilaos, the Tampon area and the Ramparts valley, which is typical of significant sulfur concentration. At 06:00 UTC (10 h LT), the boundary layer thickness had increased and the tracer was modelled high above the surface, generally between 2500 and $3000 \mathrm{~m}$ a.s.l. As a consequence, the occurrence of the tracer load up to $2 \%$ is more homogeneous and is simulated from the south-west to the east of the vent. In this case, the mean distance of the tracer load presence does not exceed $20 \mathrm{~km}$ from the vent. A strong plume occurrence (load up to 20\%) was modelled at 06:00 UTC north of the vent above the Plaine des Palmistes. In the afternoon (12:00 UTC, 16 h LT) the altitude of the plume was generally simulated up to $3000 \mathrm{~m}$ a.s.l. and was less influenced by the topography. At this altitude, horizontal winds are stronger and vertically sheared due to the trade wind inversion. This can be observed on Fig. 3 where the tracer plume is advected over longer distances. Four zones with up to $2 \%$ of tracer load are simulated to the west, north, northeast and east of the vent and attain up $50 \mathrm{~km}$ of distance. This location of the tracer plume is not typical with regards to the mean regime of the trade winds over La Réunion island (Fig. 1). It also reveals that the transport of gas emitted inside the caldera of the PdF is strongly influenced by local circulation. Figure 4 gives the occurrence of the tracer load between 24 August and 31 October modelled by FLEXPART. The field is quite different from the one simulated in May. The significant differences in forecasted plume dispersion, in spite of the close location of the sources and of the similar injection height of the modelled plume, are attributed to a significant evolution of the weather conditions between the two periods. Overall, the sulfur load is simulated west of the vent and to a lesser extent to the north. At night (18:00 and 00:00 UTC) a maximum of the tracer presence (up to $20 \%$ ) is modelled west of the volcano above the Rivière des Ramparts valley. The field of the tracer concentration (not shown) suggests that this local maximum is due to an accumulation of nocturnal pollution trapped within deep valleys. In the morning (06:00 UTC, $10 \mathrm{~h} \mathrm{LT})$ the distribu- 
Table 2. Summary of flights made by the ultralight aircraft during the volcanic ash events of May-September 2015.

\begin{tabular}{|c|c|c|c|c|c|}
\hline Date & $\begin{array}{r}\text { Take off } \\
\text { time (UTC) }\end{array}$ & $\begin{array}{r}\text { Acquisition } \\
\text { duration }(m n)\end{array}$ & $\begin{array}{r}\text { Maximum } \mathrm{SO}_{2} \\
\text { mixing ratio (ppb) }\end{array}$ & $\begin{array}{l}\text { Maximum number } \\
\text { concentration of } \\
\text { particles }\left(\mathrm{cm}^{-3}\right)\end{array}$ & $\begin{array}{l}\text { Comments on } \\
\text { data collected }\end{array}$ \\
\hline $19 / 05 / 2015$ & $04: 47$ & 60 & - & 44680 & No $\mathrm{SO}_{2}$ data \\
\hline 20/05/2015 & $04: 53$ & 60 & 744.5 & 33554 & Good sampling \\
\hline $22 / 05 / 2015$ & $04: 54$ & 55 & 382.8 & 19837 & Good sampling \\
\hline $25 / 05 / 2015$ & $04: 39$ & 60 & 282.8 & 18500 & Good sampling \\
\hline 26/05/2015 & $03: 57$ & 51 & 33.7 & 436 & $\begin{array}{l}\text { Good sampling, } \\
\text { end of the eruption }\end{array}$ \\
\hline 01/08/2015 & $05: 38$ & 60 & 2530.0 & 60310 & Good sampling \\
\hline 25/08/2015 & $07: 21$ & 60 & - & 48700 & No $\mathrm{SO}_{2}$ data \\
\hline 26/08/2015 & $07: 12$ & 60 & - & 31020 & $\mathrm{No} \mathrm{SO}_{2}$ data \\
\hline 27/08/2015 & 06:11 & 63 & - & 73020 & No $\mathrm{SO}_{2}$ data \\
\hline 28/08/2015 & $04: 57$ & 60 & 105.7 & 14510 & Good sampling \\
\hline 29/08/2015 & $03: 34$ & 64 & 3330.0 & 65850 & Good sampling \\
\hline $31 / 08 / 2015$ & $04: 42$ & 60 & 669.0 & 31710 & Good sampling \\
\hline 01/09/2015 & $04: 56$ & 58 & 2004.0 & 65250 & Good sampling \\
\hline 02/09/2015 & $04: 25$ & 60 & 804.5 & 43450 & Good sampling \\
\hline 03/09/2015 & $04: 29$ & 60 & 626.3 & 41270 & Good sampling \\
\hline $10 / 09 / 2015$ & $07: 19$ & 67 & 2339.0 & 17367 & Good sampling \\
\hline $11 / 09 / 2015$ & $04: 39$ & 78 & 12.7 & 5025 & Good sampling \\
\hline 18/09/2015 & 05:02 & 66 & 472.0 & 43130 & Good sampling \\
\hline
\end{tabular}

tion of the tracer load occurrence is close to that simulated at 00:00 UTC. However, the field is more homogeneous and has a greater horizontal extension, showing that the boundary layer thickness has increased. The tracer plume is located at a higher altitude which makes it less influenced by the topography. In the afternoon (12:00 UTC, 16 h LT), this process is more marked and the fields are homogeneous around the vent except at the south-east where the presence of the tracer is low. The presence of the tracer load is mainly modelled to the west and south-west from the vent above the area of the cities of Le Tampon and Saint-Pierre. This well-marked distribution shows that, during the period, the trade winds were essentially zonally oriented near the vent. According to the FLEXPART model, the number of days on which the plume of the tracer could interact directly with the Maïdo observatory is less frequent over the August-October period (not shown).

\subsection{Plume geometry and gas emissions at the volcanic vent}

Plume geometry (height, direction) and $\mathrm{SO}_{2}$ emission rates $\left(\mathrm{td}^{-1}\right)$ are presented in Figs. 5 and 6. They have been compared along with daily rain data measured at the OVPF Châteaufort station, near the south-eastern base of the summit cone in order to give an indication of the quality of the results. DOAS sessions are acquired with a sampling rate of typical on flux measurement every 5-10 min, and correspond on average to $1 / 3$ of the total daytime, because the DOAS stations use ultraviolet light as the source of radiation. Ex-

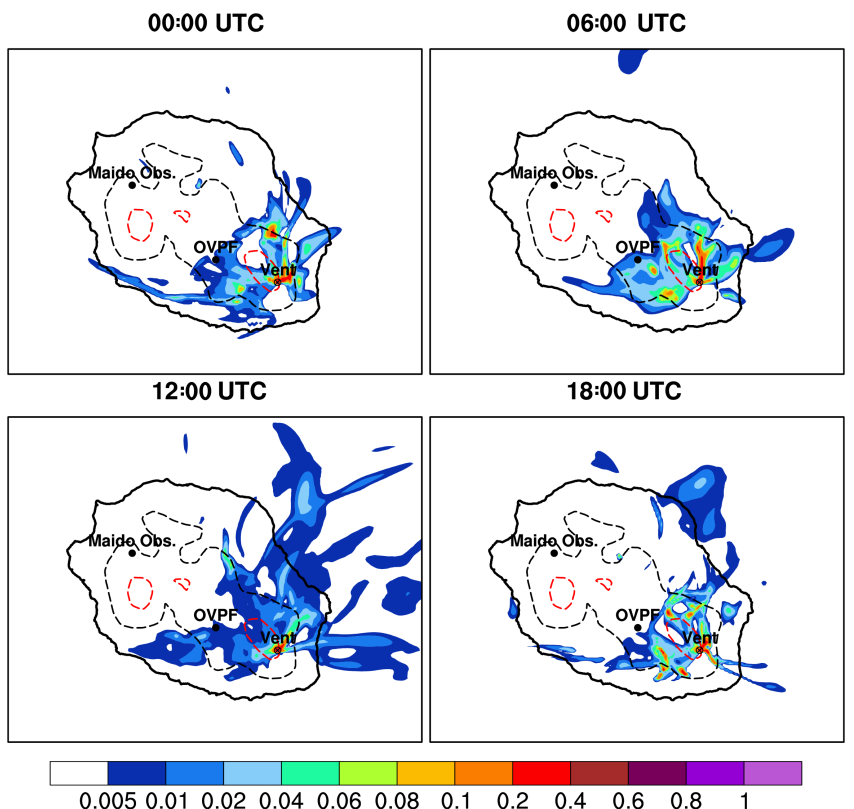

Figure 3. Normalised hourly temporal mean of a tracer (representing the $\mathrm{SO}_{2}$ ) load integrated over all model levels emitted at the vent and simulated by FLEXPART between 17 May at 00:00 UTC and 31 May at 23:00 UTC. The locations of the Maïdo observatory, the OVPF and the vent are indicated on the figure. The dotted lines show the $1000 \mathrm{~m}$ a.s.l. (black) and $2000 \mathrm{~m}$ a.s.l. (red) topography level contours. 
00:00 UTC

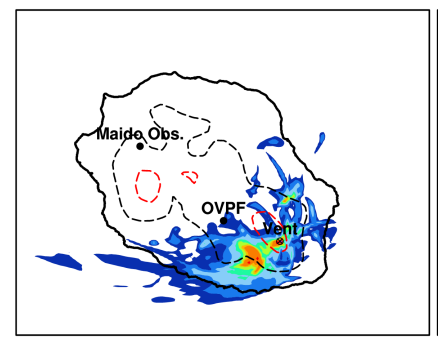

12:00 UTC

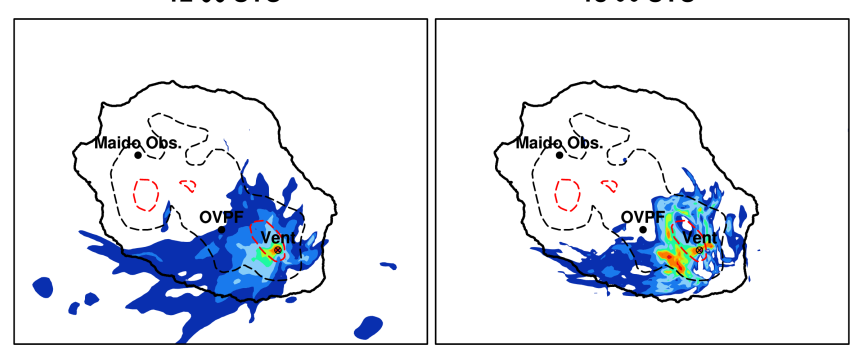

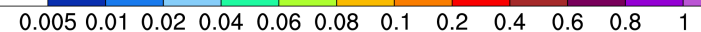

Figure 4. Same as Fig. 3 but for a simulation between 24 August at 00:00 UTC and 31 October at 23:00 UTC.

trapolation of the average $\mathrm{SO}_{2}$ fluxes measured during this time window to the whole day duration may cause an observational bias. Nevertheless, interesting comparison with independent data sets is still possible. Plume directions were mostly blowing south-westwards during the daytime (wind direction $=57 \pm 25^{\circ}, n=780$ ), consistent with FLEXPART simulations (Fig. 5). Plume directions are only partially consistent with wind directions measured close to the ground at the Bellecombe station, possibly reflecting a wind rotation with elevations, since the plume height was up to $4-5 \mathrm{~km}$ above sea level. Differences in directions are increasingly consistent with increasing plume height and increasing wind speed (Fig. 5). The plume height varies during the eruption, reflecting the eruptive intensity and modulation by local meteorological conditions. It was consistently above the level of the volcano summit and on several occasions above the boundary layer. The $\mathrm{SO}_{2}$ flux is reported on Fig. 6 as daily mean values and standard errors. On 18 May, the mean $\mathrm{SO}_{2}$ emission measured by DOAS reached $1870 \mathrm{td}^{-1}$. In relation to this strong emission period, high $\mathrm{SO}_{2}$ concentrations up to $95 \mathrm{ppm}(95000 \mathrm{ppb})$ were recorded on 19 May at 13:00 UTC above the vent during the helicopter flight. Higher concentrations (up to $167 \mathrm{ppm}$ ) were also recorded in the near-vent ground-based experiments. Two other phases of high mean emissions at 1000 and $1840 \mathrm{t} \mathrm{d}^{-1}$ were measured during the second eruption at the beginning of September and at midOctober respectively. The daily average was computed by weighting each measurement by its uncertainty and duration. This is necessary because, as can be seen in Fig. 7, the uncertainty varies among individual measurements due to changing measurement conditions, and in some cases can be quite high. The main sources of uncertainty are uncontrolled radiative transfer effects (Kern et al., 2010), and uncertainties in the plume speed. However, plume height and direction also determine whether a scanner is capable of completely covering a plume cross section or not. As the August eruption started at night-time, the DOAS network partly missed the initial, intense, but short-lived phase of high output rate on 24 August. During this phase, kilometre-long eruptive fissures opened at the south-western foot of the summit cone. The opening of a small short-lived vent on the north-western flank of the cone shows that the feeder dyke initially crossed the entire summit cone (Fig. 8). We estimate that maximum lava output rate on 25 August on the basis of $\mathrm{SO}_{2}$ fluxes is still in the range $24-37 \mathrm{~m}^{3} \mathrm{~s}^{-1}$ (depending on the assumed initial amount of dissolved $\mathrm{SO}_{2}$ ). Volcanic activity evolved rapidly into a single-emitting source and the eruption focused to build a single and large eruptive cone, feeding a broad lava field (Fig. 8). The temporal trend in $\mathrm{SO}_{2}$ emission, together with satellite data on lava fluxes (Coppola et al., 2017), permit the following phases of the major 2015 eruption to be identified:

- Phase 1 (24 August 2015-10 September 2015) involves an initial slightly decreasing phase of lava output, and moderate $\mathrm{SO}_{2}$ emissions, following a short-lived initial opening phase of intense effusion during the first day.

- Phase 2 (11 September 2015-13 October 2015) is a month-long phase of increasing lava and $\mathrm{SO}_{2}$ emission rates.

- Phase 3 (14 October 2015-1 November 2015) comprises three short-lived (ca. 2-day-long) pulses of lava and $\mathrm{SO}_{2}$ emissions.

Peaks in instantaneous (i.e. single scan) $\mathrm{SO}_{2}$ fluxes were highest (in the range $5-6 \mathrm{kt} \mathrm{d}^{-1}$ ) at the beginning of the eruption (25-27 August) and in the period 25 September to 30 October. Bulk rock analysis suggest that the increase in lava and $\mathrm{SO}_{2}$ emission rates during phase 2 is linked to a change in magma composition. During most of the eruption, $\mathrm{SO}_{2}$ fluxes have been lower than $1.5-2 \mathrm{kt} \mathrm{d}^{-1}$. In the $11-$ 17 September period, very low $\mathrm{SO}_{2}$ emission rates $(<300$ and $600 \mathrm{td}^{-1}$ respectively) were estimated. Possibly, these weak emissions may correspond to a phase of low altitude of the gas plume, mostly confined inside the Enclos Fouque caldera, during the end of phase 1 . Weak emissions in the 1-6 October period might be related to a phase of intense rain, which might have partly scavenged $\mathrm{SO}_{2}$ from the atmosphere and introduced radiative transfer effects on the flux measurements (e.g. Kern et al., 2010). NOVAC data suggest that magma and gas output rate and magma effusion rate increased during the second part of phase 2 (i.e. between 8 and 18 October). Interestingly, the strong increase in mass flow rate on 15-17 October is associated with a strong increase in gas plume height (up to $5.1 \mathrm{~km}$ above sea level) 

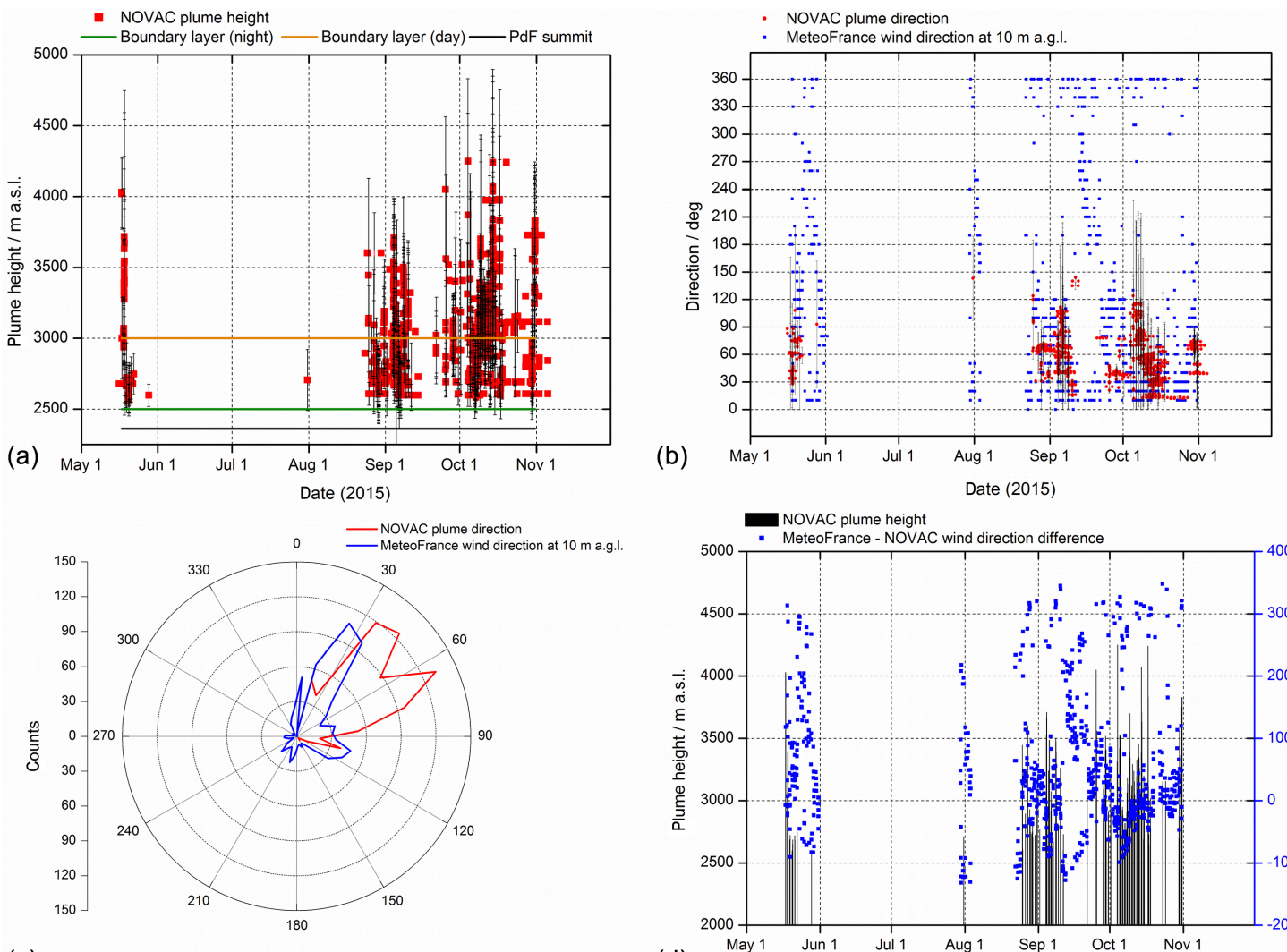

(c)

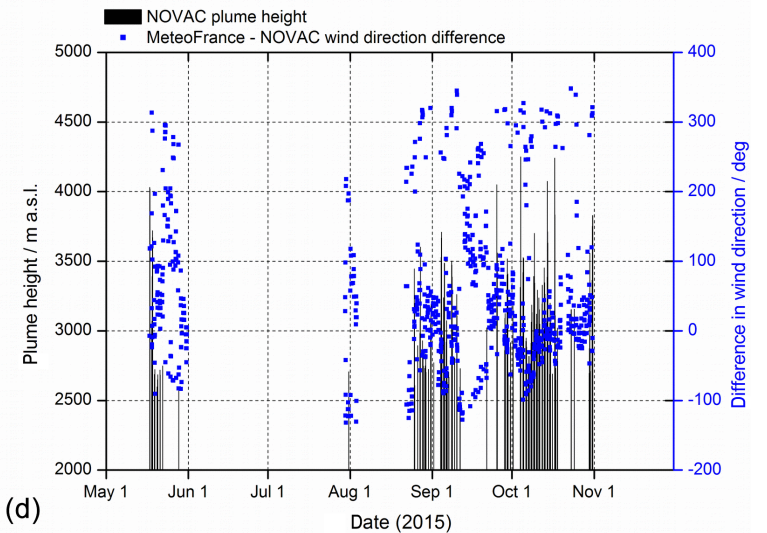

Figure 5. Time evolution of the plume height (a) and plume direction (b) computed by triangulation of nearly simultaneous scans of two permanent DOAS stations of OVPF (NOVAC network) and by the Météo-France station. (c) Wind rose of the wind direction as indicated by the plume trajectory measured by the scanners, and wind direction measured by the meteorological station. (d) Difference between the plume direction derived by DOAS and the wind direction at the Bellecombe Météo-France station, and plume height.

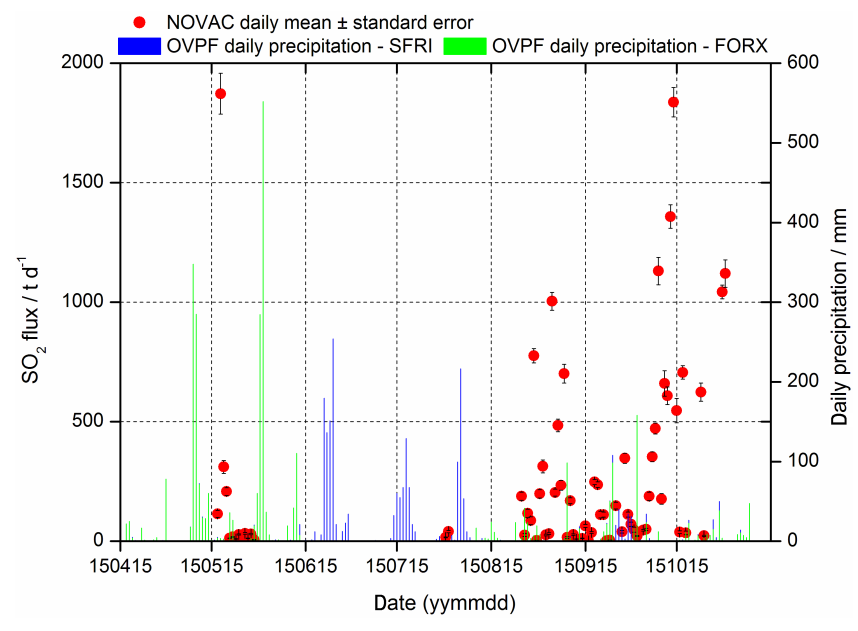

Figure 6. Estimated daily mean $\mathrm{SO}_{2}$ emission $\left(\mathrm{td}^{-1}\right)$ obtained by integrating the DOAS plume scans with the wind speed provided by Météo-France (Bellecombe station). Daily precipitations are from the SFRI and Châteaufort (FORX) stations of OVPF located respectively at the top and at the SE base of the central cone. over the period $16-18$ of October. During the pulsating final phase (phase 3 ) of the eruption, $\mathrm{SO}_{2}$ emissions were stronger during the second and final eruptive pulse (Figs. 6 and 7). During the first eruptive pulse of phase 3, fast lava propagation triggered a major fire and aerosol/ash emissions from the southern walls of the Enclos Fouqué caldera. Using the Hibert et al. (2015) approach and average daily $\mathrm{SO}_{2}$ emission rates a total lava bulk volume of $21-39 \mathrm{M} \mathrm{m}^{3}$ is obtained. This value is similar but on average lower than that estimated by photogrammetry $\left(36 \pm 3 \mathrm{M} \mathrm{m}^{3}\right.$; see Peltier et al., 2016) and by satellite data $\left(45 \pm 15 \mathrm{M} \mathrm{m}^{3}\right.$; see Coppola et al., 2017). As discussed by Coppola et al. (2017), pre-eruptive $S$ degassing of shallow stored magma might explain this discrepancy. This hypothesis is consistent with the preliminary analysis of MultiGAS data, which confirms previous findings at Piton the la Fournaise that concentrated, high-temperature gases are water dominated (Di Muro et al., 2016b). The MultiGAS data acquired in near-field studies suggest that high-temperature gases emitted in 2015 had high $\mathrm{H}_{2} \mathrm{O} / \mathrm{CO}_{2}$ molar ratios (May: $126 \pm 102$ and AugustOctober: $116 \pm 48$ ) and that $S$ was the second most abundant species before $C\left(\mathrm{CO}_{2} / \mathrm{SO}_{2}\right.$ molar ratio measured in 


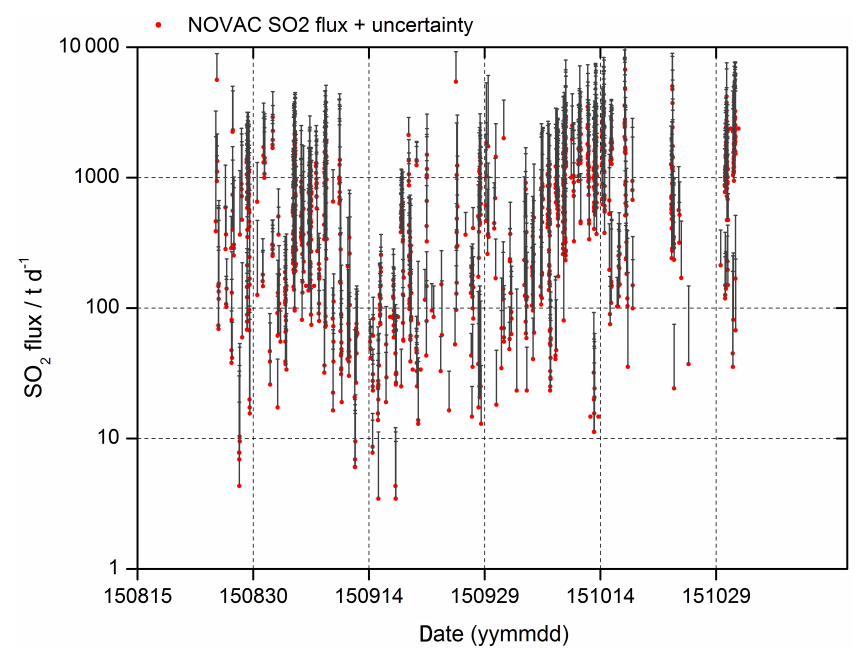

Figure 7. $\mathrm{SO}_{2}$ emission $\left(\mathrm{t} \mathrm{d}^{-1}\right)$ from individual scan measurements of the DOAS network (red) during the large August-October 2015 eruption. The uncertainty comes from the spectroscopic retrieval, radiative transfer, wind direction and speed and plume height. This uncertainty is used in the computation of the daily mean values as presented in Fig. 6.

2015 is $<0.6) . \mathrm{CO}_{2} / \mathrm{SO}_{2}$ ratios increased only slightly from May $(0.12 \pm 0.07)$ to August $(0.19 \pm 0.23)$. The combination of DOAS and MultiGAS permits an estimation that the May eruption emitted a minimum of $258 \mathrm{kt} \mathrm{H}_{2} \mathrm{O}, 4.8 \mathrm{kt} \mathrm{SO}$ and $0.8 \mathrm{kt} \mathrm{CO}_{2}$, while the August-October eruption emitted $2649 \mathrm{kt} \mathrm{H}_{2} \mathrm{O}, 33.8 \mathrm{kt} \mathrm{SO} \mathrm{C}_{2}$ and $9.3 \mathrm{kt} \mathrm{CO}_{2}$. The May eruption was fed by a single and relatively homogeneous magmatic source, while the long-lasting August eruption involved at least two magma sources during phases 1 and 2 (Di Muro et al., 2016a). However, evolved and degassed magmas were largely dominant during the whole sequence of 2015 eruptions. These events provoked the progressive draining of the upper and chemically zoned portion of the volcano feeding system and were triggered by the ascent of new deep inputs.

\subsection{Examples of volcanic plume distribution and chemical properties}

On 21 May 2015, the plume was forecasted by FLEXPART to be located west of the volcano (Fig. 9). We therefore performed measurements between Saint-Pierre and the OVPF site in Bourg Murat in order to cross the plume with our mobile lidar system. Figure 9 shows the time series of the backscattered signal along the track. The plume is clearly visible and seems to flow along the relief with a quasi-constant vertical extension from 0 to $1200 \mathrm{~m}$ a.g.l. (the blank period was due to a failure of the system). The high values of the backscattered signal observed at the track's start are plausibly due to a mixing of volcanic and marine aerosols, the latter increasing notably the aerosol loading close to the coast. Figure 9 shows the extinction profile retrieved using simul-
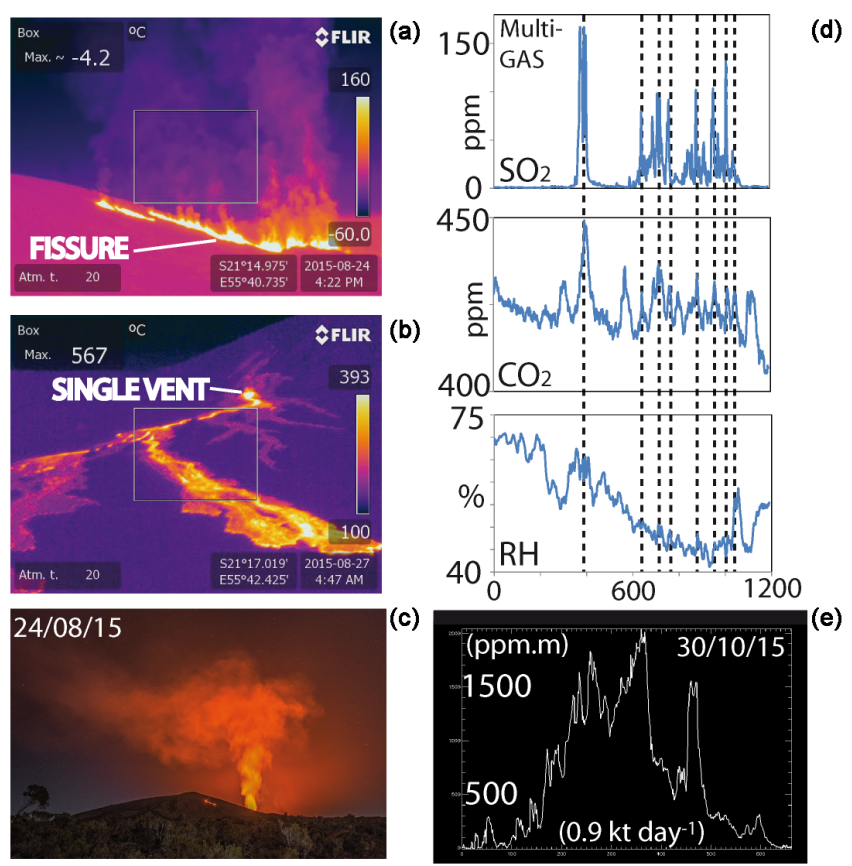

Figure 8. Night-time IR remote imagery (view from the Piton de Bert site on the southern cliff of the Enclos Fouqué caldeira (see Fig. 1) of the linear eruptive sources active at the beginning (a) and on the fourth day (b) of the major August 2015 eruption. (c) Tall gas and aerosol plume emitted by the linear source active at the beginning of the August 2015 eruption. (d) In situ analysis of volcanic gas emissions by the MultiGAS technique performed close to the eruptive vent (25 August 2015 eruption). Lines mark peaks which have been correlated in order to calculate molar ratios. (e) $\mathrm{SO}_{2}$ column density measured on 30 October 2015 by portable mini-DOAS in a traverse of the gas plume (Plaine des Sables site: $4.3 \mathrm{~km}$ northwest from the eruptive vent).

taneous sun photometer measurements at 06:14 UTC (vertical black dashed line on Fig. 9). The measured $\mathrm{AOT}_{355}$ and Ångström ( $\mathrm{A})$ coefficient between 500 and $675 \mathrm{~nm}$ are $0.20 \pm 0.05$ and $0.91 \pm 0.14$ respectively, and the retrieved $\mathrm{LR}$ at $355 \mathrm{~nm}\left(\mathrm{LR}_{355}\right)$ is $63 \pm 16 \mathrm{sr}$. The extinction profile shows a vertical extension of the plume up to $2500 \mathrm{~m}$ a.s.l. with a maximum extinction value of $0.19 \mathrm{~km}^{-1}$ reached at $2200 \mathrm{~m}$ a.s.l. and a second maximum value of $0.16 \mathrm{~km}^{-1}$ reached at $1100 \mathrm{~m}$ a.s.l. The complex structure of this observed aerosol extinction profile is probably due to the mixing of (i) sea salt and anthropogenic pollution-loaded coastal air masses lifted up by the sea breeze (Lesouëf et al., 2011) and (ii) volcanic aerosol-loaded air masses flowing down the slope. In this case, each aerosol type (oceanic, anthropogenic, and volcanic) brings its own contribution to the observed $\AA$ and $\mathrm{LR}_{355}$ values, which reflect this aerosol mixture (see Cattrall et al. (2005) for typical values of optical aerosol parameters observed for oceanic and anthropogenic urban aerosols). In addition, the processes influencing the volcanic aerosol growth (such as coagulation) could impact the ob- 


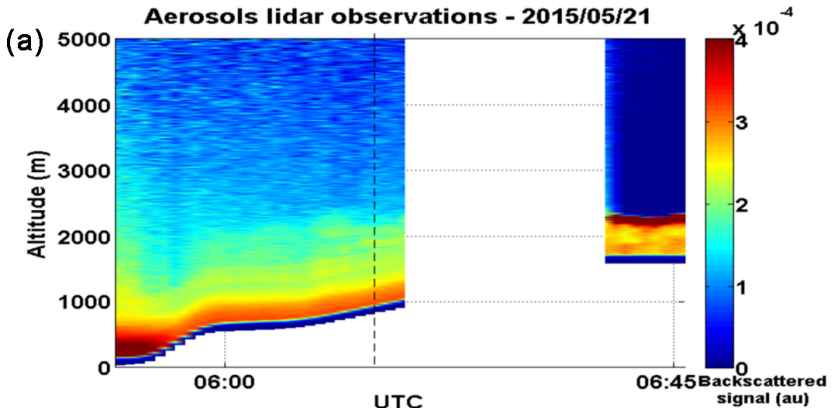

(b) 21 May 2015 at 07:00 UTC

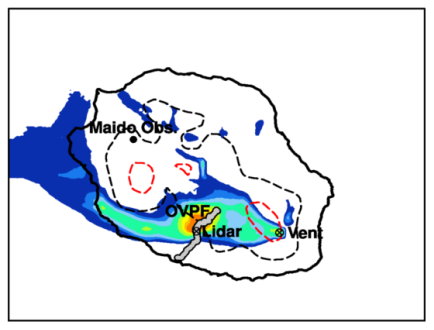

$\begin{array}{lllllll}0.001 & 0.01 & 0.04 & 0.08 & 0.2 & 0.4 & 1\end{array}$ (c) 21 May 2015 at 07:00 UTC

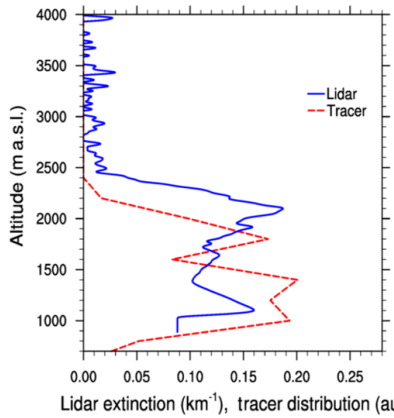

Figure 9. (a) Backscattered signal (arbitrary unit) along the 21 May pick-up truck's track (grey line on the bottom left panel). The black dashed line shows the profile used to retrieve the extinction profile shown in the bottom right panel. (b) FLEXPART simulation of the volcanic tracer load modelled on 21 May at 06:00 UTC and the trace of the pick-up truck path (grey line). (c) Aerosols extinction profile retrieved on 21 May 2015 06:14 UTC (blue line) and tracer profile simulated by FLEXPART at the same location at 06:00 UTC (dashed red line).

served size of the encountered aerosols. Figure 9 also shows the tracer profile simulated by FLEXPART at 06:00 UTC $(10 \mathrm{~h} \mathrm{LT})$ at the same location. Note that this approach allows an assessment of the ability of the model to simulate the tracer vertical distribution, not the resulting extinction profile. In other words, the simulated distribution can only be compared qualitatively to the observed one. Moreover, the model provides hourly outputs, which prevents us from comparing the simulated distribution at the exact same time of the observations. Finally, the model only simulates the volcanic tracer distribution, and does not take into account other types of aerosol (marine and anthropogenic in our case), possibly encountered and mixed with the volcanic ones. Having these caveats in mind, one can see that the model shows the same vertical plume extension up to $2500 \mathrm{~m}$ a.s.l., and the same two tracer loading peaks at 1000 and $2000 \mathrm{~m}$ a.s.l., which are shifted $200 \mathrm{~m}$ below the observed ones. However, in contrast to the observations, a higher loading is simulated at $1000 \mathrm{~m}$ than at $2000 \mathrm{~m}$. On 2 September 2015, the plume was forecasted to be located north-west of the volcano. Two maxima were modelled by FLEXPART (above the OVPF and above the Maido area) in relation to the evolution of the wind intensity above the vent. The lidar was

consequently installed at the OVPF $(16 \mathrm{~km}$ north-west from the volcanic vent, Fig. 10). On Fig. 10, the aerosol layer is clearly visible between approximately 1600 and $3000 \mathrm{~m}$ a.s.l. (0 and $1500 \mathrm{~m}$ a.g.l.) with a highly loaded aerosol layer up to $2100 \mathrm{~m}$ a.s.l. (500 $\mathrm{m}$ a.g.1.). The lidar backscattered signal increases from 2.2 up to 2.6-3.5 (au) between 0 and $500 \mathrm{~m}$ a.g.l. at 10:30 UTC (14:30 h LT) until the end of the measurement period. This shows the passage of a freshly emitted aerosol plume that likely comes from the vent. Figure 10 shows the extinction profile retrieved using simultaneous sun photometer measurements during this fresh aerosol passage at 13:10 UTC (17:10 h LT; vertical black dashed line on Fig. 10). The measured $\mathrm{AOT}_{355}$ and $\AA$ are $0.15 \pm 0.04$ and $1.26 \pm 0.19$ respectively, and the retrieved $L^{2} R_{355}$ equals $42 \pm 10 \mathrm{sr}$. The extinction profile locates the plume top at $3000 \mathrm{~m}$ a.s.l. ( $1400 \mathrm{~m}$ a.g.l.) and shows the highest aerosol loading below $2400 \mathrm{~m}$ a.s.l. ( $800 \mathrm{~m}$ a.g.l.) with a maximum value of $0.20 \mathrm{~km}^{-1}$ reached at $2000 \mathrm{~m}$ a.s.l. ( $400 \mathrm{~m}$ a.g.l.). The relatively high $\AA$ value $(1.26 \pm 0.19)$ measured in this case indicates the presence of small particles and the retrieved $\mathrm{LR}_{355}$ value $(42 \pm 10 \mathrm{sr})$ is in agreement with LR values retrieved by Pisani et al. (2012) for freshly emitted volcanic aerosols $(30-45 \mathrm{sr}$ at $532 \mathrm{~nm}$ at about $7 \mathrm{~km}$ from the Etna summit crater). These observations are therefore in agreement with the hypothesis of a fresh volcanic plume partially made of sulfuric acid aerosols. The tracer profile simulated by FLEXPART (Fig. 10) shows a plume located between 2600 and $3000 \mathrm{~m}$ a.s.l. (1000 and $1600 \mathrm{~m}$ a.g.l.). This poor agreement between the simulation and the observation in this case is visible on Fig. 10, which shows that the OVPF site is located at the very edge of the simulated plume. Figures 11 and 12 show examples of the evolution of $\mathrm{SO}_{2}$ and aerosol concentrations measured along the aircraft trajectories on 1 and 2 September 2015. The results of the trajectory analysis show that trade winds turned the volcanic aerosol plume towards the north-west of La Réunion during these flights. An even stronger rotation is observed when comparing modelled dispersion at 06:00 UTC (Fig. 11) with that at 13:00 UTC (Fig. 10). On 1 September 2015, the aircraft entered the plume at an altitude of around $2.5 \mathrm{~km}$ a.s.l. in agreement with DOAS scans. Outside the plume, low mixing ratios of $\mathrm{SO}_{2}(\sim 10 \mathrm{ppb})$ were detected, most likely due to the remote location of La Réunion, situated far from major anthropogenic influences. By entering the volcanic aerosol plumes, the concentration of $\mathrm{SO}_{2}$ increased dramatically up to $2004 \mathrm{ppb}$. The particle number concentration reached $65250 \mathrm{~cm}^{-3}$ within the volcanic cloud and was highly correlated to $\mathrm{SO}_{2}$ concentration. Meanwhile, there was a moderate increase in coarse particle concentrations (particle diameter $D_{\mathrm{p}}>1 \mu \mathrm{m}$ ). It is very likely that the particles in the volcanic plume were generated by oxidation of volcanic $\mathrm{SO}_{2}$ and subsequent particle nucleation or by condensation of volatile compounds onto pre-existing fine particles $\left(D_{\mathrm{p}}<1 \mu \mathrm{m}\right)$. The $\mathrm{SO}_{2}$ and submicron aerosols observed by the aircraft were concentrated in a narrow well-defined plume of about $14 \mathrm{~km}$ 
horizontal width. The dispersion of the volcanic plume simulated by the FLEXPART model is compared with in situ airborne observations in Fig. 11. $\mathrm{SO}_{2}$ was carried out as a tracer for volcanic emissions and plume transport in the dispersion model. The simulations successfully represent the main flow directions of the volcanic plume and the pronounced $\mathrm{SO}_{2}$ concentrations to the west of the vent that could be observed by in situ measurements. The good correspondence between measurements and simulations suggests that the plume transport is well characterised by the model. The potential of retrieving plume trajectories in combination with in situ measurements provides relevant information to explore physico-chemical transformations inside the volcanic plume as the plume ages. The next day, the width of the aerosol plume was determined during the climb phase of the aircraft between 04:26 and 04:43 UTC. A $600 \mathrm{~m}$-thick aerosol plume could be identified at an altitude around $2300 \mathrm{~m}$ a.s.l. Along this flight, the aircraft entered inside the plume several times at a distance of $2-6 \mathrm{~km}$ away from the vent. Peaks of $\mathrm{SO}_{2}$ mixing ratio and particle number concentrations up to $804 \mathrm{ppb}$ and $43450 \mathrm{~cm}^{-3}$ were measured during the plume traverses. The ratio between the $\mathrm{SO}_{2}$ and the observed particle number concentration is not constant when the aircraft is above the boundary layer (i.e. above $1000 \mathrm{~m}$ a.s.l. at this period of the day). This clearly shows that the processes of oxidation of the volcanic $\mathrm{SO}_{2}$ into $\mathrm{H}_{2} \mathrm{SO}_{4}$, the nucleation of $\mathrm{H}_{2} \mathrm{SO}_{4}$ and the coagulation of fine particles are complex and need to be analysed in detail. It will be the subject of a dedicated study. The particle size distributions of coarse particles in the volcanic aerosol plume had a similar pattern to those in the volcanic aerosol-free air masses at the same altitude (around $2.6 \mathrm{~km}$ a.s.1.) and do not indicate the sole presence of volcanic particles. The evolution of the $\mathrm{SO}_{2}$ mixing ratio measured at the Maïdo observatory in 2015 is shown in Fig. 13. The impact of the volcanic plume is clearly visible during a few days in May when the $\mathrm{SO}_{2}$ measurements started, and frequently during the SeptemberOctober period. Interestingly, the impact is stronger during the short-lived small volume eruption of May than during the large long-lasting eruption of August-October. Moreover, the impact of the August-October eruption is larger during its weaker phase (September) than during the intense phase of activity recorded later on. Bulk aerosol samples were collected only under free tropospheric conditions (between 18:00 and 01:00 UTC) on a weekly basis. Filter samples $(0.5 \mu \mathrm{m}$ pore size diameter Teflon) were analysed for the main anions and cations by ion chromatography. Figure 13 also shows the temporal variation sulfate collected on aerosol filter. When the Piton de la Fournaise was active ( $\mathrm{SO}_{2}$ showing large concentrations), sulfate showed clear peak concentrations up to 2 to $3 \mu \mathrm{g} \mathrm{m}^{-3}$ in September 2015 . We have averaged $\mathrm{SO}_{2}$ data to match the sampling period of filter aerosols (between 18:00 and 01:00 UTC). The calculated molecular ratio $\mathrm{SO}_{2} / \mathrm{SO}_{4}^{2-}$ at night gives 534, 23 and 8 on 20 May, 1 September and 1 October respectively. The strong variability of this ratio needs to be further examined. It could be attributable to the strong seasonal variability of UV at La Réunion and thus to the concentration of oxidants like hydroxyl radical. The maximum daily UV index measured in clear sky by the Bentham spectrometer (Brogniez et al., 2016) at the OPAR site of Saint-Denis (80 m a.s.1., Fig. 1) is consistent with this assumption. The evolution of the UV index measured was 6.68 on 20 May, 8.35 on 1 September and 11.26 on 12 October 2015 . We chose to focus on two contrasted 2-day periods in terms of $\mathrm{SO}_{2}$ mixing ratio in order to investigate the nucleation process within the volcanic plume. On 20 and $21 \mathrm{May}, \mathrm{SO}_{2}$ mixing ratio reached 433.5 and $288.1 \mathrm{ppb}$, while on 1 and 2 September, mixing ratios of $\mathrm{SO}_{2}$ are 81.3 and $7.9 \mathrm{ppb}$ (Fig. 13). For these two distinct periods, examples of the evolution of the ion and aerosol size distribution issued from the combination of the AIS and DMPS measurements are shown, for 20-21 May and 1-2 September respectively (Fig. 14). The concentration of the smallest size distribution $(1-10 \mathrm{~nm})$ increases in the morning (around 06:00 UTC/10 h LT). Examples of the fast growth of cluster ions to larger sizes can be followed on the DMPS size distributions up to $50 \mathrm{~nm}$ on 1-2 September, and $100 \mathrm{~nm}$ on 20-21 May. The concentration of newly formed and grown particles is also significantly higher for the May period. The aerosol number concentration in the $10-20 \mathrm{~nm}$ size range (Fig. 15) reaches $4 \times 10^{4}$ and $2.5 \times 10^{5} \mathrm{~cm}^{-3}$ on 20 and 21 May and $6 \times 10^{4}$ and $5 \times 10^{4} \mathrm{~cm}^{-3}$ on 1 and 2 September. The order of magnitude of the aerosol number concentration observed during these periods is significantly higher than observed in non-eruptive periods. Daily maximum concentration at the Maïdo is about $3 \times 10^{3} \mathrm{~cm}^{-3}$ in normal condition and can reach $2 \times 10^{4} \mathrm{~cm}^{-3}$ when the observatory is under the influence of anthropogenic pollution. These differences show that most of the particles measured on 20-21 May and on 1-2 September have a volcanic origin. The sudden decrease in particle concentration between 16:00 and 18:00 UTC ( 20 and $22 \mathrm{~h} \mathrm{LT}$ ) is likely due to a shift of air mass due to nocturnal stratification and consequent location of the Maïdo observatory in the free troposphere. The morning advection of a relatively wide range of ultrafine particles $\left(D_{\mathrm{p}}<100 \mathrm{~nm}\right)$ to the Maïdo station indicates that nucleation and early growth already took place at the vicinity of the crater and continued within the plume at least up to the Maïdo station. Due to its low saturated vapour pressure under typical atmospheric temperatures (Marti et al., 1997), the common assumption in the scientific community is that the sulfuric acid is the main gas responsible for the nucleation processes. This particle is predominantly produced by the oxidation of $\mathrm{SO}_{2}$ emitted at the volcanic vent. We estimated the $\mathrm{H}_{2} \mathrm{SO}_{4}$ concentration from the $\mathrm{SO}_{2}(\mathrm{ppb})$ concentration, the radiation $\left(\mathrm{W} \mathrm{m}^{-2}\right)$, the relative humidity $(\%)$ and the condensation sink (Pirjola et al., 1999) using the empirical proxy proposed by Mikkonen et al. (2011). Unlike other parameters, for instance anthropogenic pollutants, the variation of $\mathrm{SO}_{2}$ concentration is not periodic because it depends 


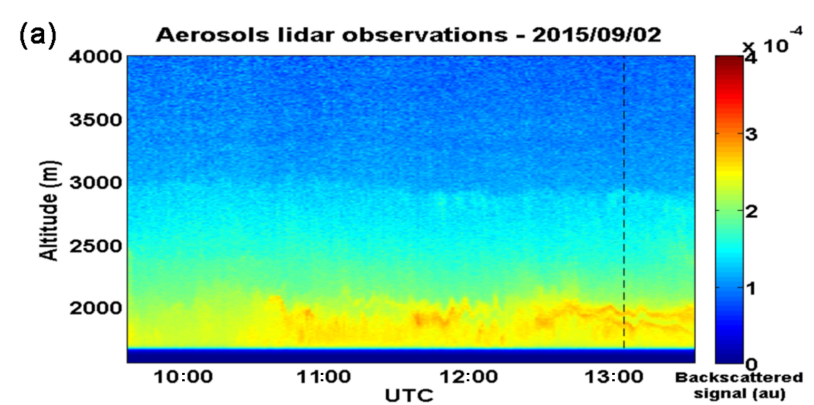

(b) 2 Sep 2015 at 13:00 UTC
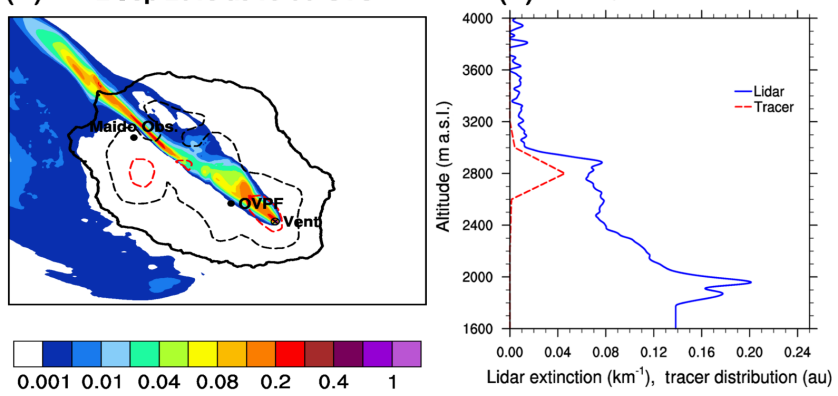

Figure 10. (a) Time series of the backscattered signal (arbitrary unit) and profile (black dashed line) located at the OVPF site on 2 September 2015 and used to retrieve the extinction profile shown in the bottom right panel. (b) FLEXPART simulation of the volcanic tracer load modelled on 2 September 2015 at 13:00 UTC and location of the pick-up truck (OVPF). (c) Aerosol extinction profile retrieved on 2 September 2015 at 13:10 UTC (blue line) and tracer profile simulated by FLEXPART at the same location at 13:00 UTC (dashed red line).

on whether the volcanic plume is advected to the station or not. Except on 20 May, when early morning $\mathrm{SO}_{2}$ data are missing, we observe that the $\mathrm{H}_{2} \mathrm{SO}_{4}$ concentration rises synchronously with the ion concentration (around 06:00 UTC) and approximately $2 \mathrm{~h}$ before the increase in the concentration of $10-20 \mathrm{~nm}$ particles. The time delay between the increase in $\mathrm{H}_{2} \mathrm{SO}_{4}$ and in the particle concentration is likely due to the time for new $1 \mathrm{~nm}$ clusters to grow into the 10 $20 \mathrm{~nm}$ size range. The AIS size distributions indeed show that ions in the $1-10 \mathrm{~nm}$ size range appear only $1 \mathrm{~h}$ after the rise in $\mathrm{H}_{2} \mathrm{SO}_{4}$ concentration. However, the concentration of 10 $20 \mathrm{~nm}$ particles is not directly linked to the concentration of $\mathrm{H}_{2} \mathrm{SO}_{4}$, although globally $\mathrm{H}_{2} \mathrm{SO}_{4}$ is higher during the May period, as are the concentrations of the 10-20 nm particles. For the case of 20 May, it is possible that newly formed particles are grown by condensation to sizes above the detection limit of our instrumentation. Indeed, large number concentrations of particles larger than $20 \mathrm{~nm}$ are detected on this day. Other factors influence the concentration of particles in the 10-20 nm size range, such as the condensational sink (higher during the May period) and coagulation effects. These factors should be taken into account to further calculate nucleation rates and their link to $\mathrm{H}_{2} \mathrm{SO}_{4}$.

\section{(a) 1 Sep 2015 at 06:00 UTC}

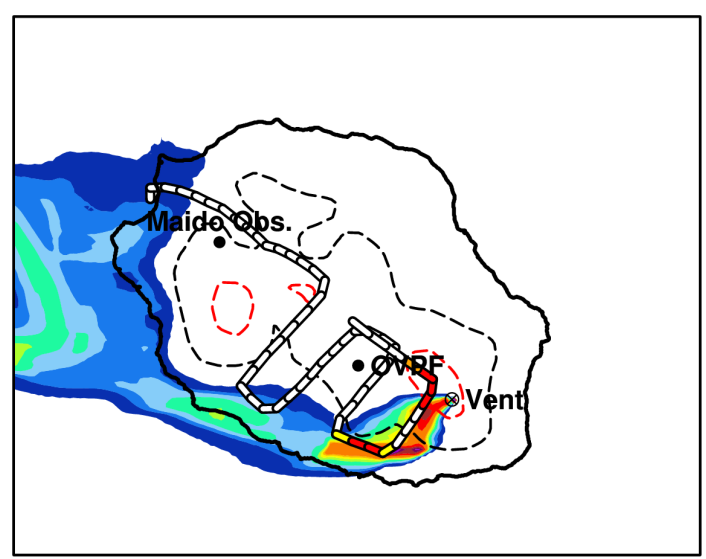

(b) 2 Sep 2015 at 06:00 UTC

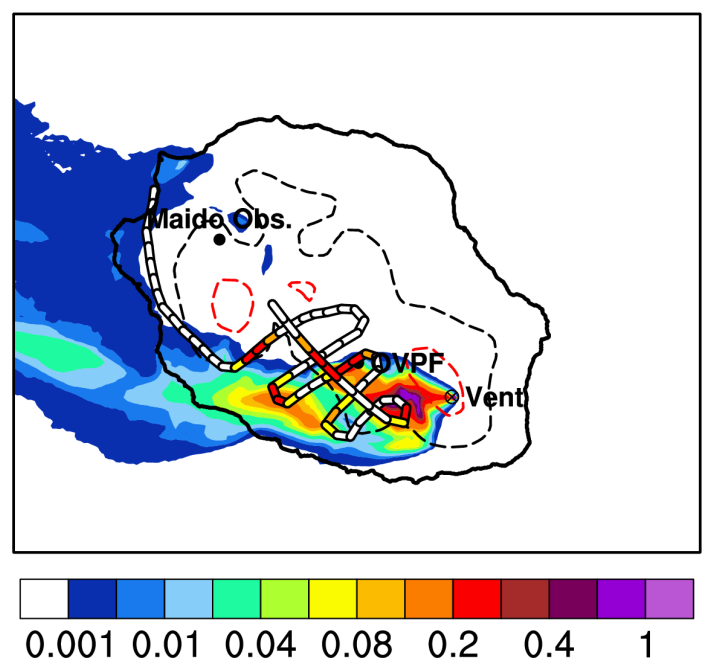

Figure 11. Relative mixing ratio of the tracer load emitted at the vent and simulated by FLEXPART on 1 September 2015 (a) and on 2 September 2015 (b). The flight path is coloured as a function of the measured $\mathrm{SO}_{2}$ mixing ratio (white for less than $100 \mathrm{ppb}$, yellow between 100 and $200 \mathrm{ppb}$, orange between 200 and $400 \mathrm{ppb}$ and red for more than $400 \mathrm{ppb}$ ). The dotted lines show the 1000 (black) and $2000 \mathrm{~m}$ a.s.l. (red) topography.

\section{Discussion}

The data set acquired in the frame of the 2015 STRAP experiments have permitted a detailed characterisation of hightemperature gas emissions for the first time during two typical end-member eruptions of Piton de la Fournaise (May: small and rapidly declining; August-October: large and complex). The permanent DOAS network has provided a detailed and time-resolved measurement of plume geometry (altitude, direction of dispersion) as well as of the rate of $\mathrm{SO}_{2}$ emission during the daytime. The derived plume height shows reasonable agreement with simultaneous ultralight aircraft and lidar measurements, while some differences are found with ground meteorological stations, because of meteorolog- 

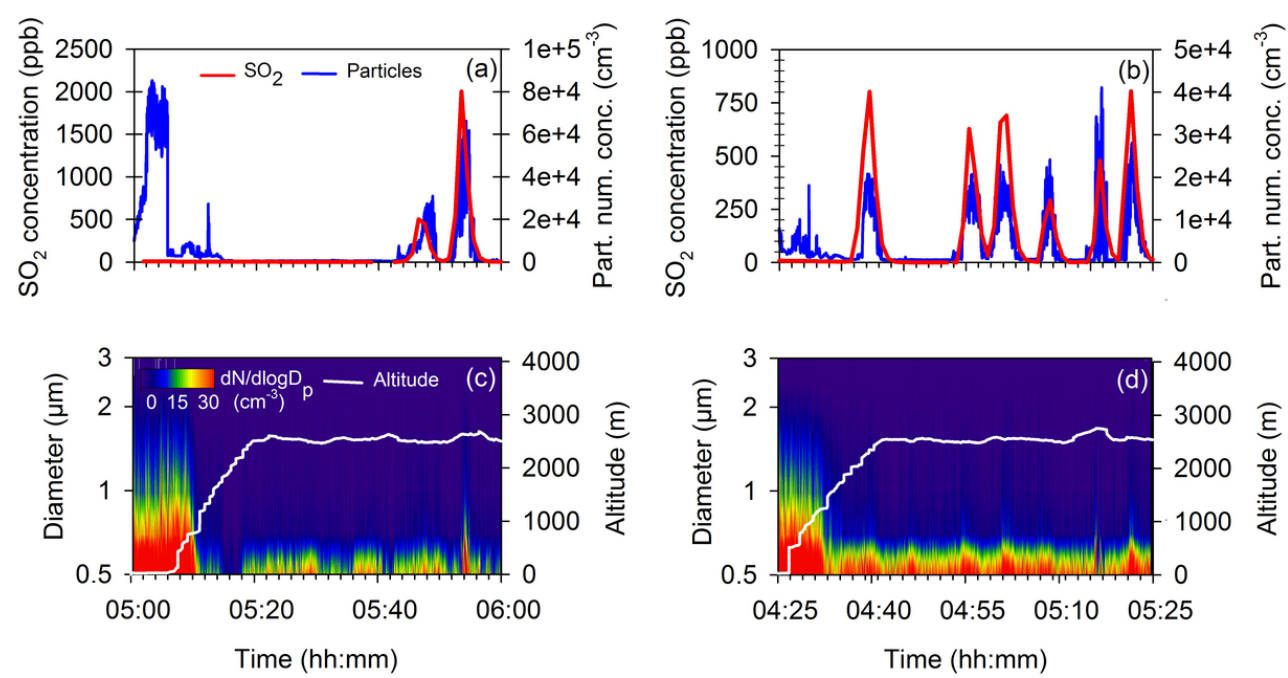

Figure 12. On-board ultralight aircraft measurements sampled on 1 September 2015 (a, c) and 2 September 2015 (b, d) over La Réunion. (a, b) Time series of $\mathrm{SO}_{2}$ mixing ratio (ppb, red line) and particle number concentration $\left(\mathrm{cm}^{-3}\right.$, blue line). (b, c) Particle number size distribution (colour) and altitude of the aircraft (white line). The trajectories of the flights are pointed out on Fig. 11.

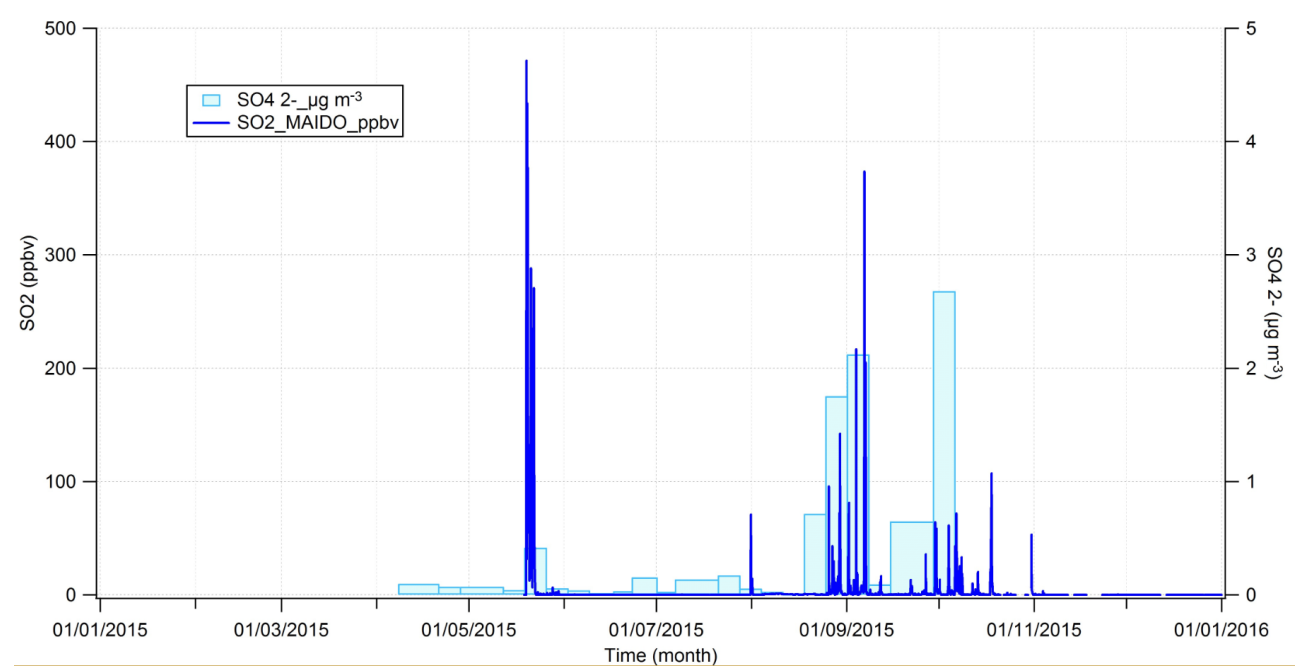

Figure 13. Time series of the $\mathrm{SO}_{2}$ mixing ratio (ppb) measured at the Maïdo observatory in the year 2015. Measurements started on 19 May. Time series of $\mathrm{SO}_{4}^{2-}$ concentration $\left(\mu \mathrm{g} \mathrm{m}^{-3}\right)$ from filter sampled at the Maïdo observatory integrated each week at night (between 18:00 and 01:00 UTC).

ical and topographical effects. During the short-lived May eruption, the $\mathrm{SO}_{2}$ emissions declined rapidly in time, as is often observed in typical eruptions of Piton de la Fournaise. A much more complex time evolution was traced during the long-lasting August-October eruption, showing a marked increase in emission rates in its second half. Preliminary analyses of the erupted lavas highlight the involvement of several magmatic sources during the second large eruptive event. Nevertheless, near-vent MultiGAS experiments reveal that both eruptions emitted gases largely dominated by water vapour and with low $\mathrm{CO}_{2} / \mathrm{SO}_{2}$ ratios $(<0.6)$. This is consistent with the extrusion of relatively evolved and degassed magmas stored in the plumbing system during the 20102014 phase of volcano inactivity. Coupling $\mathrm{SO}_{2}$ fluxes and $\mathrm{CO}_{2} / \mathrm{SO}_{2}$ and $\mathrm{H}_{2} \mathrm{O} / \mathrm{SO}_{2}$ ratios has permitted an estimation of the budget of the main high-temperature gases $\left(\mathrm{H}_{2} \mathrm{O}, \mathrm{SO}_{2}\right.$ and $\mathrm{CO}_{2}$ ) emitted at the vent by PdF eruptions for the first time. These results are key parameters that will be introduced in mesoscale chemical models to represent the life cycle of the volcanic plume. FLEXPART simulations of transportdiffusion of a volcanic tracer allowed for drawing up a climatology of the plume distribution on the two most important eruptive periods (May and August-October 2015). Overall, the model shows a marked diurnal evolution. During the 

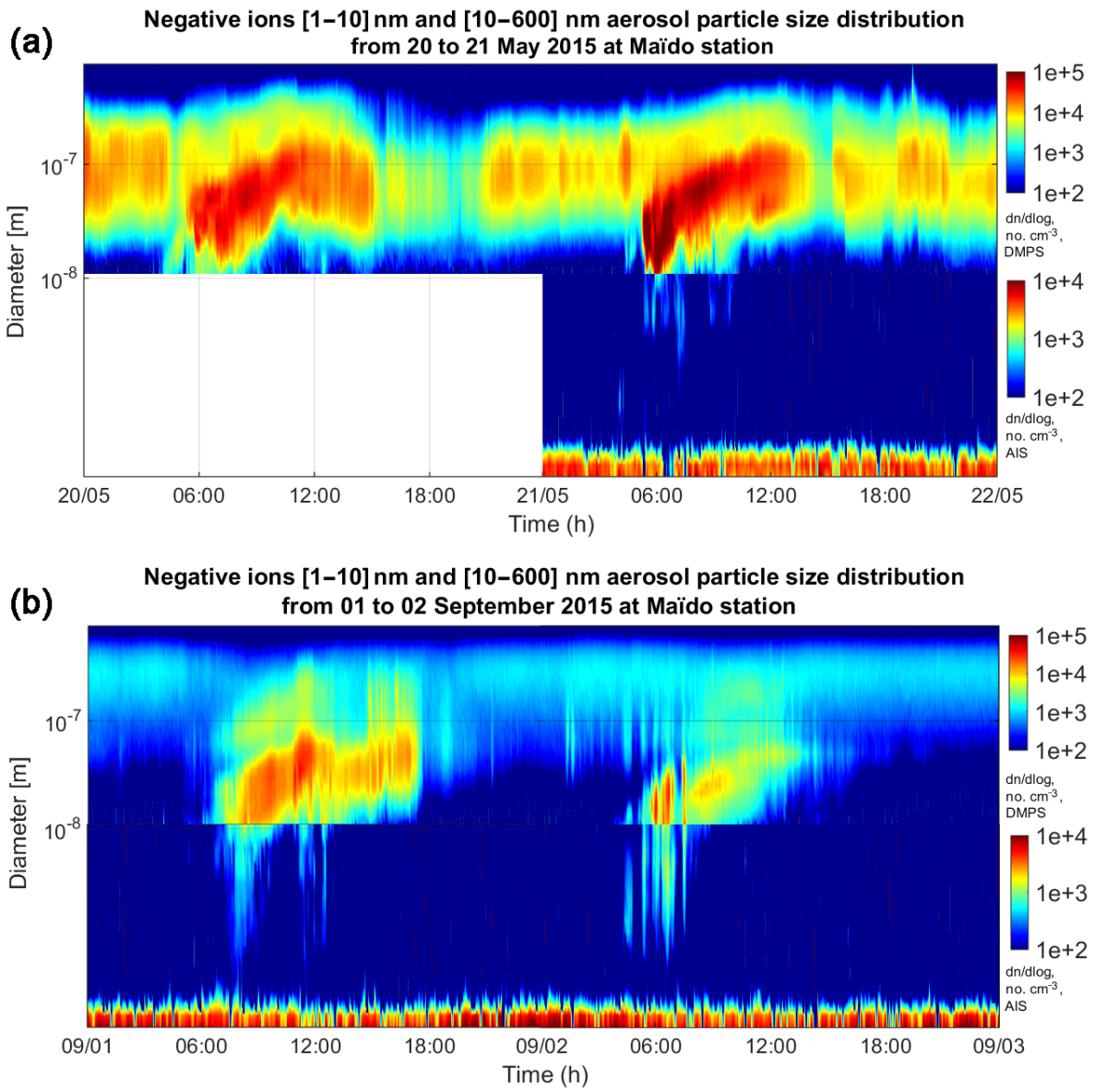

Figure 14. Negative ions $(1-10 \mathrm{~nm})$ and $(10-600 \mathrm{~nm})$ aerosol particle size distributions measured (a) on 20-21 May 2015 and (b) on 23 September when the Piton de la Fournaise plume crossed the Maïdo station. No AIS data are available between 20 May at 00:00 UTC and 21 May at 05:00 UTC. Colour scale (right) indicates the ratio $d \mathrm{~N} / d \log$ in $\mathrm{cm}^{-3}$.

night-time and in the early morning, the FLEXPART model forecasts the occurrence of areas with strong pollutants accumulation in regions with rugged topography such as the Rempart valley or the cirque of Cilaos. In the afternoon, the model forecasts higher plume altitude and that in turn results in a more homogeneous distribution of the pollution due to the increase in thickness of the mixing boundary layer. The lidar measurements (600 profiles) over the study period have permitted a climatology of the plume altitude and thickness to be drawn. The distal thickness of the plume varies between 700 and $2000 \mathrm{~m}$ with a top around $3000 \mathrm{~m}$ a.s.l. that can reach $4000 \mathrm{~m}$ a.s.l. during the most intense activity periods. The comparisons between the lidar measurements and the FLEXPART simulations have enabled us to assign some aerosol layers to the volcanic plume. In the distal area, most of the time, the layer associated with the volcanic plume is located at $2000 \mathrm{~m}$ a.s.l. which roughly corresponds to the altitude of the vent. Compared with DOAS observations, the distal lidar measurements generally constrain the altitude of the plume to a lower level than the one measured near the eruptive vent. The decrease in plume height with the distance from the vent could be attributed to a subsidence of the weak eruptive plume due to an orographic effect during its advection to the north-west. Another reason could be related to the definition of the plume height: in the case of DOAS, it corresponds to the altitude of the column-weighted centre of mass of the plume while, in the case of lidar measurements, it corresponds to the base of the plume. The combination of the sun photometer measurements and of the backscattered signal of the lidar gives the aerosol optical thickness, the Ångström coefficient, the lidar ratio and the optical extinction profile of the aerosols. In the layers attributed to the freshly emitted volcanic plume, the extinction coefficient reaches $0.20 \mathrm{~km}^{-1}$, the Ångström coefficient between 500 and $675 \mathrm{~nm}$ is $1.26 \pm 0.19$ and the lidar ratio at $355 \mathrm{~nm}$ equals $42 \pm 10 \mathrm{sr}$. These last values reveal the dominant presence of small particles and are in agreement with previously published studies. A more detailed analysis of the various $\mathrm{AOT}_{355}, \AA$ A, $\mathrm{LR}_{355}$ and extinction profiles observed and retrieved during the 2015 Piton de la Fournaise's eruptions will be the subject of a dedicated study. The airborne measurements consistently show the presence of the volcanic plume 
(a)

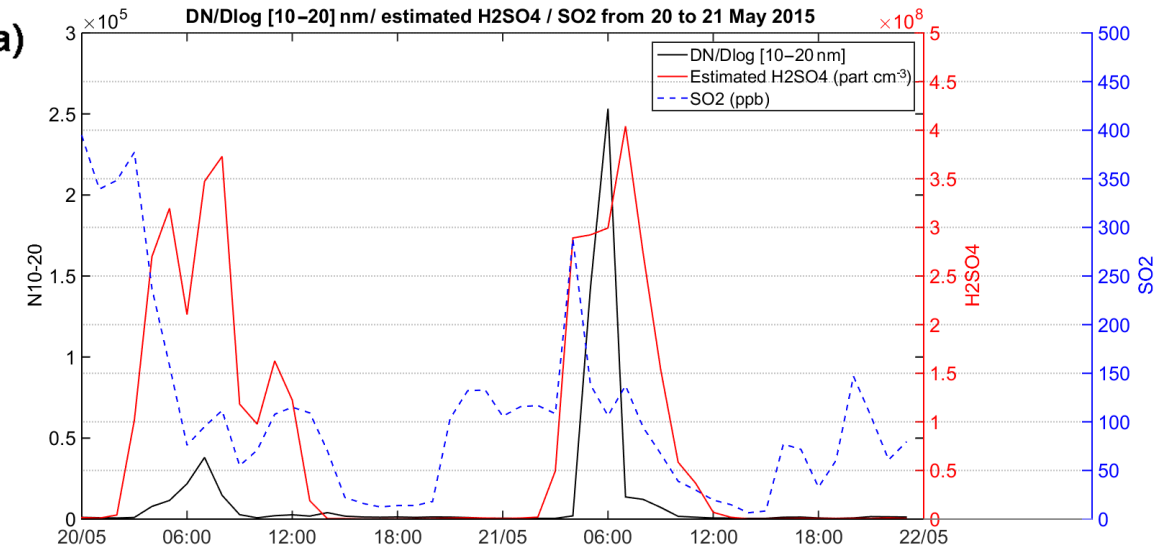

(b)

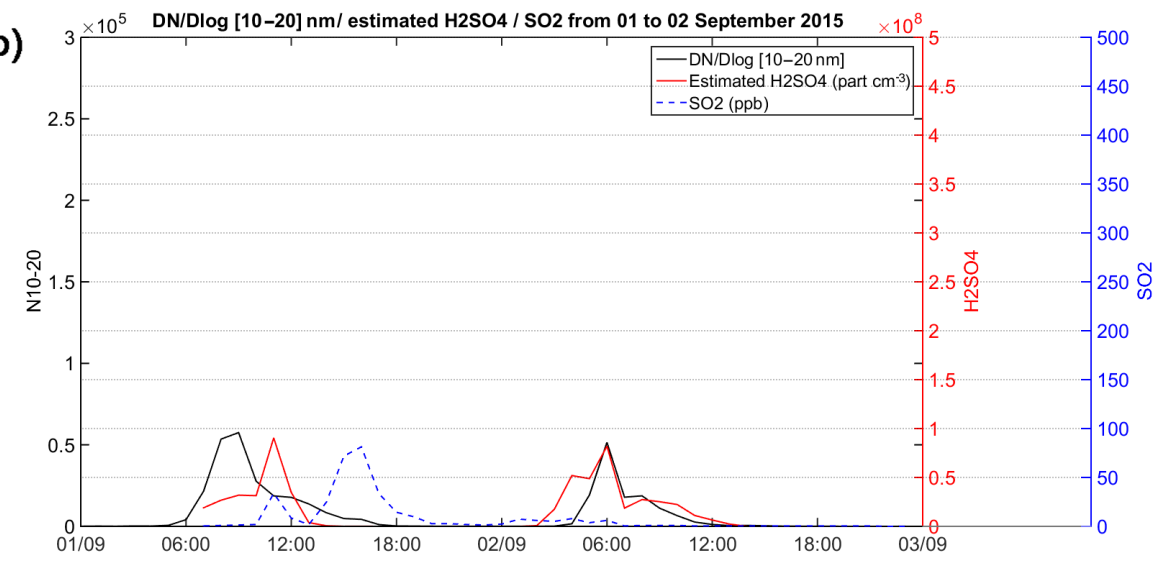

Figure 15. Time series of the 10-20 nm particle concentrations (black), $\mathrm{SO}_{2}$ mixing ratio (ppb in blue) and $\mathrm{H}_{2} \mathrm{SO}_{4}$ concentration estimated by proxy ( $\mathrm{cm}^{-3}$ in red) on 20-21 May 2015 (a) and on 1-2 September 2015 (b).

at about $2000 \mathrm{~m}$ a.s.l. in the distal area. $\mathrm{SO}_{2}$ mixing ratios measurements are very high with levels sometimes exceeding $3000 \mathrm{ppb}$ a few kilometres away from the vent. Strong $\mathrm{SO}_{2}$ mixing ratios above $1000 \mathrm{ppb}$ are frequently measured over $20 \mathrm{~km}$ of distance from the Piton de la Fournaise. The measured aerosol size distribution shows the predominance of small particles in areas with high $\mathrm{SO}_{2}$ concentration. Inside the plume, the number of particles greater than $7 \mathrm{~nm}$ is also very high, reaching 40000 and $70000 \mathrm{~cm}^{-3}$. The combination of extinction coefficient given by the aerosol lidar and the size distribution observed by the ultralight aircraft will give us the detailed physical and chemical properties of aerosols within the volcanic plume. Together with the MultiGas measurements on board the helicopter and close to eruptive vents, the ultralight measurements appear to be the most direct in situ measurements reported until now in the eruption plume of the PdF. Several measurements clearly show the passage of the volcanic plume over the Maïdo observatory. In particular, on 20 and 21 May, the $\mathrm{SO}_{2}$ mixing ratio reached $433 \mathrm{ppb}$. The combined measurements of SMPS, nanoCPC and AIS highlight a strong rate of sulfuric acid nucleation. The size distribution of the smallest ions $(1-10 \mathrm{~nm})$ increases in the early morning (around 06:00 UTC). The appearance of the cluster ions is rapidly followed by their fast growth from 10 to $50 \mathrm{~nm}$ on 1-2 September, and to $100 \mathrm{~nm}$ on 20-21 May. An analytic computation of the $\mathrm{H}_{2} \mathrm{SO}_{4}$ concentration derived from solar radiation and the $\mathrm{SO}_{2}$ concentration indicates that $\mathrm{H}_{2} \mathrm{SO}_{4}$ and the ion concentrations increase simultaneously in the morning. The AIS size distributions show that ions in the $1-10 \mathrm{~nm}$ size range appear only $1 \mathrm{~h}$ after rise in the $\mathrm{H}_{2} \mathrm{SO}_{4}$ concentrations. The preliminary correlation between proximal and distal observation suggests that weak eruptions like May 2015 or the weaker phases of the long-lasting AugustOctober eruption have a stronger impact on the distal site of Maïdo, with respect to the strongest eruptive phases. We speculate that low plume height during weak eruptive phases favours plume subsidence and enhances interaction with the rugged topography of the island. The surface air pollution is then stronger around the volcano area which can represent a currently underestimated source of risk for the highly populated slopes of the volcano. 


\section{Conclusions}

The STRAP 2015 campaign was dedicated to the observation and study of diluted volcanic plumes of the Piton de la Fournaise volcano. Plume tracking was performed during two eruptions of Piton de la Fournaise (May 2015 and August-October 2015), representative of two distinct end members of the activity of the volcano. The first one was short lived and was emitting a small volume of lava, while the second one had a long duration, a high intensity and a complex time evolution. This campaign, conducted over an extended period, required a significant human and scientific investment and a major effort for coordination of a multidisciplinary international team. These new results have been made possible by sustained efforts of cross-disciplinary collaborations between volcanologists and meteorologists, developing shared scientific language, methods and objectives during several years. After 3.5 years of rest, the reawakening of Piton de la Fournaise in 2014 and the escalation of volcanic activity in 2015 provided a unique opportunity for a major collaborative effort between several international and local partners. The 2015 STRAP experiment represents one of the first experimental campaigns, allowing careful tracking of the downwind evolution of the plume from the proximal (near the vent) to the distal area (over La Réunion island) over tens of kilometres. We want to stress here that this is the first time that such a complete and detailed geochemical data set is acquired at Piton de la Fournaise, both during shortlived (May 2015) and long-lasting (August-October 2015) eruptions. An original element of this campaign has been the possibility of highlighting the potential influence of distinct processes like (i) eruption intensity and time evolution, (ii) weather conditions and atmosphere stability and (iii) local circulation associated with the topography. Simultaneous in situ and optical measurements have been performed over several periods: near the vent (MultiGas, DOAS), in the medial area within the plume (lidar aerosol and ultralight aircraft) and in the distal area at the Maïdo observatory. All these measurements unambiguously show an important formation of fine particles within the plume. These new particles are mainly attributable to the gas-particle conversion (nucleation and condensation) of sulfuric acid. In addition, a video of the STRAP 2015 campaign highlights the main results and the observation strategy (see doi:10.5446/30633). It is now necessary to combine all these data to quantify the formation and the dimensional evolution of the submicronic aerosols (ultrafine and fine particles) according to the properties of oxidation of the atmosphere and to the seasonal cycle of UV irradiance. Ash-poor gas-rich emissions are widespread at volcanoes worldwide both during quiescence and unrest phases. The small amount of silicate ash and primary aerosol in the plumes of Piton de la Fournaise make this volcano an ideal target to better understand the time and space evolution of volcanic gas. So this database will be useful to evaluate chemistry transport models (CTMs), especially in their abil- ity to model the plume chemical composition and the impact of the local circulations on pollutant accumulation in densely populated areas (Durand et al., 2014). Then future studies will focus on the evolution of gas-particle formation in areas close to the vent with a significant presence of water and at a greater distance in a drier air mass. In particular, the variability of the correlation between the new particle formation rate and sulfuric acid will be studied. This will allow, for the first time to our knowledge, a parameterisation of nucleation rate specific to volcanic plumes to be derived. The STRAP 2015 database has made it possible to quantify the evolution of emissions, the injection height and the evolution of the optical and chemical properties of the plume during 85 days of eruption. The second part of the STRAP programme was held in July 2016 on the Etna volcano (Italy). This second campaign has allowed us to study the plume formed by continuous passive degassing. It will then be possible to compare the specificities of these two types of plume and to evaluate the nucleation and coagulation processes of these two target volcanoes.

Data availability. The database is available on the STRAP program website at http://osur.univ-reunion.fr/recherche/strap/database/. 


\section{Appendix A:}

Table A1. Summary of material collected on field near the vent on May-October 2015. Contact the OVPF/IPGP for further details about the samples.

\begin{tabular}{|c|c|c|c|c|}
\hline $\begin{array}{l}\text { Date } \\
(\mathrm{MM} / \mathrm{DD} / \mathrm{YY})\end{array}$ & $\begin{array}{l}\text { Material } \\
\text { type }\end{array}$ & Location & $\begin{array}{l}\text { Weight } \\
\text { (gr) }\end{array}$ & Note on texture/size \\
\hline $5 / 17 / 2015$ & lava & $21^{\circ} 15^{\prime} 58.9^{\prime \prime} \mathrm{S}, 55^{\circ} 42^{\prime} 59.8^{\prime \prime} \mathrm{E}$ & 1210.7 & lava \\
\hline $5 / 18 / 2015$ & lava & $21^{\circ} 15^{\prime} 26.0^{\prime \prime} \mathrm{S}, 55^{\circ} 43^{\prime} 28.4^{\prime \prime} \mathrm{E}$ & 695.7 & pyroclasts of the fountain \\
\hline $5 / 20 / 2015$ & lava & $21^{\circ} 15^{\prime} 36.36^{\prime \prime} \mathrm{S}, 55^{\circ} 43^{\prime} 37.93^{\prime \prime} \mathrm{E}$ & 311.7 & lava \\
\hline $5 / 20 / 2015$ & lava & $21^{\circ} 15^{\prime} 32.21^{\prime \prime} \mathrm{S}, 55^{\circ} 43^{\prime} 27.45^{\prime \prime} \mathrm{E}$ & 312.0 & pyroclasts of the fountain \\
\hline $5 / 20 / 2015$ & lava & $21^{\circ} 15^{\prime} 32.21^{\prime \prime} \mathrm{S}, 55^{\circ} 43^{\prime} 27.45^{\prime \prime} \mathrm{E}$ & 313.2 & pyroclasts of the fountain \\
\hline $5 / 24 / 2015$ & lava & $21^{\circ} 15^{\prime} 28.75^{\prime \prime} \mathrm{S}, 55^{\circ} 43^{\prime} 32,62^{\prime \prime} \mathrm{E}$ & 1280 & lava \\
\hline $5 / 24 / 2015$ & lava & $21^{\circ} 14^{\prime} 47.72^{\prime \prime} \mathrm{S}, 55^{\circ} 43^{\prime} 20.48^{\prime \prime} \mathrm{E}$ & 214 & scoria \\
\hline $5 / 24 / 2015$ & lava & 200 m north-west of Châteaufort & 289 & lava \\
\hline $5 / 24 / 2015$ & fumaroles & $21^{\circ} 14^{\prime} 47.73^{\prime \prime} \mathrm{S}, 55^{\circ} 43^{\prime} 20.48^{\prime \prime} \mathrm{E}$ & 264 & fumarolic deposit \\
\hline $5 / 27 / 2015$ & lava & & 682 & lava \\
\hline $8 / 25 / 2015$ & pyroclast & $21^{\circ} 15^{\prime} 19.1^{\prime \prime} \mathrm{S}, 55^{\circ} 42^{\prime} 14.9^{\prime \prime} \mathrm{E}$ & 296.0 & $\begin{array}{l}\text { pyroclast of the } \\
\text { intense cone (middle) }\end{array}$ \\
\hline $8 / 25 / 2015$ & pyroclast & $21^{\circ} 15^{\prime} 17.9^{\prime \prime} \mathrm{S}, 55^{\circ} 42^{\prime} 16^{\prime \prime} \mathrm{E}$ & 201.0 & $\begin{array}{l}\text { pyroclasts of the } \\
\text { strombolian cone (upper) }\end{array}$ \\
\hline $8 / 27 / 2015$ & lava & $21^{\circ} 15^{\prime} 31.6^{\prime \prime} \mathrm{S}, 55^{\circ} 42^{\prime} 11.4^{\prime \prime} \mathrm{E}$ & 213.0 & lava \\
\hline $8 / 27 / 2015$ & pyroclast & $21^{\circ} 15^{\prime} 31.6^{\prime \prime} \mathrm{S}, 55^{\circ} 42^{\prime} 11.4^{\prime \prime} \mathrm{E}$ & 737.0 & bombs \\
\hline $8 / 27 / 2015$ & lava & $21^{\circ} 15^{\prime} 00.44^{\prime \prime} \mathrm{S}, 55^{\circ} 42^{\prime} 11.96^{\prime \prime} \mathrm{E}$ & 696.0 & lava \\
\hline $8 / 27 / 2015$ & pyroclast & $21^{\circ} 15^{\prime} 19.1^{\prime \prime} \mathrm{S}, 55^{\circ} 42^{\prime} 14.9^{\prime \prime} \mathrm{E}$ & 86.0 & $\begin{array}{l}\text { pyroclast of the } \\
\text { intense cone (middle) }\end{array}$ \\
\hline $8 / 27 / 2015$ & pyroclast & $21^{\circ} 15^{\prime} 18.6^{\prime \prime} \mathrm{S}, 55^{\circ} 42^{\prime} 12.3^{\prime \prime} \mathrm{E}$ & - & lapilli \\
\hline $8 / 27 / 2015$ & pyroclast & $21^{\circ} 15^{\prime} 18.6^{\prime \prime} \mathrm{S}, 55^{\circ} 42^{\prime} 12.3^{\prime \prime} \mathrm{E}$ & - & lapilli \\
\hline $8 / 27 / 2015$ & pyroclast & $21^{\circ} 15^{\prime} 19.1^{\prime \prime} \mathrm{S}, 55^{\circ} 42^{\prime} 14.9^{\prime \prime} \mathrm{E}$ & 678 & lapilli \\
\hline $8 / 27 / 2015$ & fumaroles & $21^{\circ} 15^{\prime} 13.9^{\prime \prime} \mathrm{S}, 55^{\circ} 42^{\prime} 15.5^{\prime \prime} \mathrm{E}$ & 428 & on lava \\
\hline $8 / 28 / 2015$ & pyroclast & $21^{\circ} 14^{\prime} 25.2^{\prime \prime} \mathrm{S}, 55^{\circ} 42^{\prime} 16.2^{\prime \prime} \mathrm{E}$ & $<20$ & ash and lapilli \\
\hline $8 / 28 / 2015$ & pyroclast & $21^{\circ} 14^{\prime} 26.0^{\prime \prime} \mathrm{S}, 55^{\circ} 42^{\prime} 13.1^{\prime \prime} \mathrm{E}$ & 426 & ash, lapilli and bombs \\
\hline $8 / 28 / 2015$ & pyroclast & $21^{\circ} 14^{\prime} 26.0^{\prime \prime} \mathrm{S}, 55^{\circ} 42^{\prime} 13.1^{\prime \prime} \mathrm{E}$ & $<10$ & lapillis \\
\hline $8 / 28 / 2015$ & pyroclast & $21^{\circ} 15^{\prime} 00.3^{\prime \prime} \mathrm{S}, 55^{\circ} 42^{\prime} 18.5^{\prime \prime} \mathrm{E}$ & $<15$ & lapillis \\
\hline $8 / 28 / 2015$ & pyroclast & $21^{\circ} 14^{\prime} 59.9^{\prime \prime} \mathrm{S}, 55^{\circ} 42^{\prime} 17.6^{\prime \prime} \mathrm{E}$ & 799 & lapillis and bombs \\
\hline $8 / 28 / 2015$ & pyroclast & $21^{\circ} 15^{\prime} 19.1^{\prime \prime} \mathrm{S}, 55^{\circ} 42^{\prime} 14.9^{\prime \prime} \mathrm{E}$ & 330 & lapillis \\
\hline $9 / 01 / 2015$ & lava & $21^{\circ} 15^{\prime} 29.28^{\prime \prime} \mathrm{S}, 55^{\circ} 42^{\prime} 14.46^{\prime \prime} \mathrm{E}$ & 1236 & lava \\
\hline $9 / 03 / 2015$ & lava & $21^{\circ} 15^{\prime} 26.1^{\prime \prime} \mathrm{S}, 55^{\circ} 42^{\prime} 12.9^{\prime \prime} \mathrm{E}$ & 713 & lava \\
\hline $9 / 03 / 2015$ & pyroclast & $21^{\circ} 15^{\prime} 19.1^{\prime \prime} \mathrm{S}, 55^{\circ} 42^{\prime} 14.9^{\prime \prime} \mathrm{E}$ & 298 & $\begin{array}{l}\text { lapilli and bombs } \\
\text { (dense and golden pumice) }\end{array}$ \\
\hline 09/07/2015 & pyroclast & $21^{\circ} 15^{\prime} 18.1^{\prime \prime} \mathrm{S}, 55^{\circ} 42^{\prime} 11.7^{\prime \prime} \mathrm{E}$ & 625 & lapilli and bombs (dense) \\
\hline 09/07/2015 & pyroclast & $21^{\circ} 15^{\prime} 18.1^{\prime \prime} \mathrm{S}, 55^{\circ} 42^{\prime} 11.7^{\prime \prime} \mathrm{E}$ & 89 & lapilli and bombs (golden) \\
\hline 09/07/2015 & pyroclast & $21^{\circ} 15^{\prime} 18.1^{\prime \prime} \mathrm{S}, 55^{\circ} 42^{\prime} 11.7^{\prime \prime} \mathrm{E}$ & $<27$ & Pele's hairs, fines and lapilli \\
\hline 09/07/2015 & pyroclast & $21^{\circ} 15^{\prime} 18.1^{\prime \prime} \mathrm{S}, 55^{\circ} 42^{\prime} 11.7^{\prime \prime} \mathrm{E}$ & 433 & lapilli and bombs \\
\hline 09/11/2015 & pyroclast & $21^{\circ} 15^{\prime} 18.1^{\prime \prime} \mathrm{S}, 55^{\circ} 42^{\prime} 11.7^{\prime \prime} \mathrm{E}$ & 1013 & bombs \\
\hline 09/11/2015 & pyroclast & $21^{\circ} 15^{\prime} 18.1^{\prime \prime} \mathrm{S}, 55^{\circ} 42^{\prime} 11.7^{\prime \prime} \mathrm{E}$ & 88 & lapillis and ash \\
\hline 09/15/2015 & pyroclast & $21^{\circ} 15^{\prime} 18.1^{\prime \prime} \mathrm{S}, 55^{\circ} 42^{\prime} 11.7^{\prime \prime} \mathrm{E}$ & 338 & lapillis and bombs \\
\hline 09/18/2015 & lava & $21^{\circ} 15^{\prime} 24.8^{\prime \prime} \mathrm{S}, 55^{\circ} 42^{\prime} 15.5^{\prime \prime} \mathrm{E}$ & 1756 & partially molten lava crust \\
\hline 09/27/2015 & lava & $21^{\circ} 15^{\prime} 33.1^{\prime \prime} \mathrm{S}, 55^{\circ} 42^{\prime} 03.35^{\prime \prime} \mathrm{E}$ & 853 & lava \\
\hline $10 / 07 / 2015$ & lava & $21^{\circ} 15^{\prime} 22.6^{\prime \prime} \mathrm{S}, 55^{\circ} 42^{\prime} 11.9^{\prime \prime} \mathrm{E}$ & 1280 & lava \\
\hline $10 / 07 / 2015$ & pyroclast & $21^{\circ} 15^{\prime} 18.1^{\prime \prime} \mathrm{S}, 55^{\circ} 42^{\prime} 11.7^{\prime \prime} \mathrm{E}$ & $<17$ & Pele's hairs, fines and lapilli \\
\hline $10 / 07 / 2015$ & lava & $21^{\circ} 15^{\prime} 22.6^{\prime \prime} \mathrm{S}, 55^{\circ} 42^{\prime} 11.9^{\prime \prime} \mathrm{E}$ & 1338 & lava \\
\hline $10 / 09 / 2015$ & lava & $21^{\circ} 15^{\prime} 34.47^{\prime \prime} \mathrm{S}, 55^{\circ} 42^{\prime} 11.14^{\prime \prime} \mathrm{E}$ & 829 & lava \\
\hline $10 / 09 / 2015$ & lava & $21^{\circ} 15^{\prime} 33.69^{\prime \prime} \mathrm{S}, 55^{\circ} 42^{\prime} 10.87^{\prime \prime} \mathrm{E}$ & 653 & lava \\
\hline
\end{tabular}


Table A1. Continued.

\begin{tabular}{|c|c|c|c|c|}
\hline $\begin{array}{l}\text { Date } \\
(\mathrm{MM} / \mathrm{DD} / \mathrm{YY})\end{array}$ & $\begin{array}{l}\text { Material } \\
\text { type }\end{array}$ & Location & $\begin{array}{l}\text { Weight } \\
\text { (gr) }\end{array}$ & Note on texture/size \\
\hline $10 / 16 / 2015$ & lava & $-21^{\circ} 15^{\prime} 18.1^{\prime \prime}, 55^{\circ} 42^{\prime} 11.7^{\prime \prime}$ & 808 & lava (spatter) \\
\hline $10 / 16 / 2015$ & lava & $-21^{\circ} 15^{\prime} 18.1^{\prime \prime}, 55^{\circ} 42^{\prime} 11.7^{\prime \prime}$ & 335 & lava (spatter) \\
\hline $10 / 23 / 2015$ & lava & $-21^{\circ} 15^{\prime} 22.6^{\prime \prime}, 55^{\circ} 42^{\prime} 11.9^{\prime \prime}$ & 440 & lava \\
\hline $10 / 23 / 2015$ & lava & $-21^{\circ} 15^{\prime} 18.1^{\prime \prime}, 55^{\circ} 42^{\prime} 11.7^{\prime \prime}$ & 66 & lapillis \\
\hline $10 / 23 / 2015$ & lava & $-21^{\circ} 15^{\prime} 18.1^{\prime \prime}, 55^{\circ} 42^{\prime} 11.7^{\prime \prime}$ & 80 & ash and lapillis \\
\hline $10 / 26 / 2015$ & pyroclast & $-21^{\circ} 14^{\prime} 49.56^{\prime \prime}, 55^{\circ} 42^{\prime} 17.46^{\prime \prime}$ & 1044 & lapillis \\
\hline $10 / 26 / 2015$ & pyroclast & $-21^{\circ} 14^{\prime} 49.56^{\prime \prime}, 55^{\circ} 42^{\prime} 17.46$ & 580 & bombs, lapillis \\
\hline $10 / 26 / 2015$ & pyroclast & $-21^{\circ} 14^{\prime} 49.56^{\prime \prime}, 55^{\circ} 42^{\prime} 17.46$ & 472 & bombs \\
\hline $10 / 26 / 2015$ & pyroclast & $-21^{\circ} 14^{\prime} 49.84^{\prime \prime}, 55^{\circ} 42^{\prime} 12.78$ & 1670 & bombs \\
\hline $10 / 26 / 2015$ & lava & $-21^{\circ} 14^{\prime} 52.13^{\prime \prime}, 55^{\circ} 42^{\prime} 18.27$ & 580 & $\begin{array}{l}\text { pahoehoe upper crust; } \\
\text { tip of the flow }\end{array}$ \\
\hline $10 / 26 / 2015$ & pyroclast & $-21^{\circ} 14^{\prime} 52.13^{\prime \prime}, 55^{\circ} 42^{\prime} 18.27$ & 250 & lapillis \\
\hline $10 / 26 / 2015$ & pyroclast & $-21^{\circ} 14^{\prime} 52.13^{\prime \prime}, 55^{\circ} 42^{\prime} 18.27$ & 662 & bombs, lapillis \\
\hline $10 / 31 / 2015$ & lava & $-21^{\circ} 15^{\prime} 22.6^{\prime \prime}, 55^{\circ} 42^{\prime} 11.9^{\prime \prime}$ & 440 & lava \\
\hline $10 / 31 / 2015$ & lava & $-21^{\circ} 15^{\prime} 22.6^{\prime \prime}, 55^{\circ} 42^{\prime} 11.9^{\prime \prime}$ & 440 & lava \\
\hline $10 / 31 / 2015$ & lava & $-21^{\circ} 15^{\prime} 22.6^{\prime \prime}, 55^{\circ} 42^{\prime} 11.9^{\prime \prime}$ & 440 & lava \\
\hline $10 / 31 / 2015$ & lava & $-21^{\circ} 15^{\prime} 22.6^{\prime \prime}, 55^{\circ} 42^{\prime} 11.9^{\prime \prime}$ & 440 & lava \\
\hline
\end{tabular}

Table A2. Summary of mini-DOAS and NOVAC scan measurements.

\begin{tabular}{|c|c|c|c|c|c|c|c|}
\hline $\begin{array}{l}\text { Date } \\
(\mathrm{MM} / \mathrm{DD} / \mathrm{YY})\end{array}$ & $\begin{array}{r}\text { Portable } \\
\text { mini-DOAS } \\
\text { begin time (UTC) }\end{array}$ & $\begin{array}{r}\text { Portable } \\
\text { mini-DOAS } \\
\mathrm{t} \mathrm{d}^{-1}\end{array}$ & $\begin{array}{r}\text { NOVAC scan } \\
\text { mid-scan } \\
\text { time (UTC) }\end{array}$ & $\begin{array}{r}\text { NOVAC scan } \\
\mathrm{td}^{-1}\end{array}$ & $\begin{array}{r}\text { NOVAC-daily } \\
\mathrm{td}^{-1}\end{array}$ & $\begin{array}{r}\text { Wind mini-DOAS } \\
\text { mini-DOAS } \\
\mathrm{m} \mathrm{s}^{-1}\end{array}$ & $\begin{array}{r}\text { Wind } \\
\text { NOVAC } \\
\mathrm{m} \mathrm{s}^{-1}\end{array}$ \\
\hline 02/05/2015 & $08: 30$ & 52 & - & - & - & 4.7 & - \\
\hline 01/06/2015 & 06:09 & 2 & - & - & - & 3.6 & - \\
\hline $05 / 18 / 2015$ & 08:01 & 234 & 08:11 & 3221 & 2704 & 2.4 & 2.4 \\
\hline $05 / 19 / 2015$ & $09: 25$ & - & $09: 23$ & 48 & 386 & 4.2 & 5.0 \\
\hline $05 / 21 / 2015$ & $06: 26$ & 568 & 05:51 & 277 & 152 & 3.9 & 2.7 \\
\hline $08 / 25 / 2015$ & $10: 20$ & - & $11: 42$ & 73 & 823 & 1.3 & 1.0 \\
\hline 09/07/2015 & $08: 22$ & 255 & $07: 34$ & 273 & 620 & 2.3 & 2.8 \\
\hline 09/11/2015 & $07: 17$ & 140 & $06: 39$ & 209 & 114 & 2.7 & 2.2 \\
\hline 09/18/2015 & $08: 22$ & 360 & $08: 13$ & 406 & 408 & 3.8 & 3.4 \\
\hline $10 / 30 / 2015$ & $10: 37$ & 893 & $06: 20$ & 1489 & 1182 & 2.8 & 2.3 \\
\hline 10/30/2015 & $11: 27$ & 1002 & $07: 27$ & 1427 & 1182 & 2.7 & 3.3 \\
\hline
\end{tabular}


Competing interests. The authors declare that they have no conflict of interest.

\section{The Supplement related to this article is available online at doi:10.5194/acp-17-5355-2017-supplement.}

Acknowledgements. The STRAP project was funded by the Agence Nationale de la Recherche (ANR-14-CE03-0004-04) and the OMNCG/OSU-R programme from La Réunion University. The DOAS stations were funded by the EU-FP6 project NOVAC. The authors acknowledge P. Goloub and PHOTONS/AErosol RObotic NETwork (AERONET) for the MICROTOPS II data processing. We also want to thank all the participants involved in STRAP in 2015 from LACy, OVPF, UMS 3365/OSU-R, LaMP, INGV, Chalmers university, Cyprus Institute, and ORA. The French Meteorological Office (DIROI/Météo-France) also helped the management of the campaign by providing a day-by-day meteorological forecasting. François Levassort is also acknowledged for his participation in the lidar measurements campaign during his vacations. The ultralight measurements would not have been possible without the availability and kindness of Didier Gouloumès from ALPHA ULM.

Edited by: J. Ma

Reviewed by: three anonymous referees

\section{References}

Ackerman, A., Kirkpatrick, M., Stevens, D., and Toon, O.: The impact of humidity above stratiform clouds on indirect aerosol climate forcing, Nature, 432, 1014-1017, doi:10.1038/nature03174, 2004.

Aiuppa, A., Baker, D., and Webster, J.: Halogens in volcanic systems, Chem. Geol., 263, 1-18, doi:10.1016/j.chemgeo.2008.10.005, 2009.

Albrecht, B.: Aerosols, cloud microphysics, and fractional cloudiness, Science, 245, 1227-1230, 1989.

Ångström, A.: The parameters of atmospheric turbidity, Tellus, 16, 64-75, 1964.

Baray, J.-L., Courcoux, Y., Keckhut, P., Portafaix, T., Tulet, P., Cammas, J.-P., Hauchecorne, A., Godin Beekmann, S., De Mazière, M., Hermans, C., Desmet, F., Sellegri, K., Colomb, A., Ramonet, M., Sciare, J., Vuillemin, C., Hoareau, C., Dionisi, D., Duflot, V., Vérèmes, H., Porteneuve, J., Gabarrot, F., Gaudo, T., Metzger, J.-M., Payen, G., Leclair de Bellevue, J., Barthe, C., Posny, F., Ricaud, P., Abchiche, A., and Delmas, R.: Maïdo observatory: a new high-altitude station facility at Reunion Island $\left(21^{\circ} \mathrm{S}, 55^{\circ} \mathrm{E}\right)$ for long-term atmospheric remote sensing and in situ measurements, Atmos. Meas. Tech., 6, 2865-2877, doi:10.5194/amt-62865-2013, 2013.

Bonali, F., Corazzato, C., and Tibaldi, A.: Identifying rift zones on volcanoes: An example from La Réunion Island, Indian Ocean, Bull. Volcanol., 295, 195-204, 2010.

Boulon, J., Sellegri, K., Hervo, M., and Laj, P.: Observations of nucleation of new particles in a volcanic plume, P. Natl. Acad. Sci. USA, 108, 12223-12226, doi:10.1073/pnas.1104923108, 2011.
Brogniez, C., Auriol, F., Deroo, C., Arola, A., Kujanpää, J., Sauvage, B., Kalakoski, N., Pitkänen, M. R. A., Catalfamo, M., Metzger, J.-M., Tournois, G., and Da Conceicao, P.: Validation of satellite-based noontime UVI with NDACC groundbased instruments: influence of topography, environment and satellite overpass time, Atmos. Chem. Phys., 16, 15049-15074, doi:10.5194/acp-16-15049-2016, 2016.

Bursik, M., Jones, M., Carn, S., Dean, K., Patra, A., Pavolonis, M., Pitman, E. B., Singh, T., Singla, P., Webley, P., Bjornsson, H., and Ripepe, M.: Estimation and propagation of volcanic source parameter uncertainty in ash transport and dispersal model: application to the Eyjafjallajöekull plume of 14-16 April 2010, Bull. Volcanol., 74, 2321-2338, 2012.

Cattrall, C., Reagan, J., Thome, K., and Dubovik, O.: Variability of aerosol and spectral lidar and backscatter and extinction ratios of key aerosol types derived from selected Aerosol Robotic Network locations, J. Geophys. Res.-Atmos., 110, d10S11, doi:10.1029/2004JD005124, 2005.

Conde, V., Robidoux, P., Avard, G., Galle, B., Aiuppa, A., Munoz, A., and Giudice, G.: Measurements of volcanic $\mathrm{SO}_{2}$ and $\mathrm{CO}_{2}$ fluxes by combined DOAS, Multi-GaS and FTIR observations: a case study from Turrialba and Telica volcanoes, Int. J. Earth Sci., 103, 2335-2347, 2014.

Coppola, D., Villeneuve, N., Di Muro, A., Ferrazzini, V., Peltier, A., Favalli, M., Bachélery, P., Gurioli, L., Harris, A., Moune, S., Vlastélic, I., Galle, N., Arellano, S., and Aiuppa, S.: Shallow system rejuvenation and magma discharge cycles at Piton de la Fournaise volcano (La Réunion Island), Earth Planet. Sci. Lett., 463, 13-24, 2017.

Di Muro, A., Métrich, N., Vergani, D., Rose, M., Armienti, P., Fougeroux, T., Deloule, E., Arienzo, L., and Civetta, L.: The shallow plumbing system of Piton de la Fournaise Volcano (La Reunion Island, Indian Ocean) revealed by the major 2007 caldera-forming eruption, J. Petrol., 55, 1287-1315, doi:10.1093/petrology/egu025, 2014.

Di Muro, A., Arellano, S., Aiuppa, S., Bachelery, P., Boudoire, G., Coppola, D., Ferrazzini, V., Galle, B., Giudice, G., Gurioli, L., Harris, A., Liuzzo, M., Métrich, N., Moune, S., Peltier, A., Villeneuve, N., and Vlastelic, I.: Eruption and degassing dynamics of the major August 2015 Piton de la Fournaise eruption, Geophysical Research Abstracts Vol. 18, EGU2016-5074, 2016 EGU General, 2016a.

Di Muro, A., Métrich, N., Allard, P., Aiuppa, A., Burton, M., Galle, B., and Staudacher, T.: Magma degassing at Piton de la Fournaise volcano, Active Volcanoes of the World series, Springer, edited by: Bachelery, P., Lenat, J. F, Di Muro, A., and Michon, L., 2016b.

Duflot, V., Royer, P., Chazette, P., Baray, J.-L., Courcoux, Y., and Delmas, R.: Marine and biomass burning aerosols in the southern Indian Ocean: Retrieval of aerosol optical properties from shipborne lidar and Sun photometer measurements, J. Geophys. Res., 116, D18208, doi:10.1029/2011JD015839, 2011.

Durand, J., Tulet, P., Filippi, J., Villeneuve, N., Leriche, M., Bhugwant, C., and Di Muro, A.: Modeling the lava heat flux during severe effusive volcanic eruption: a important impact on surface air quality, J. Geophys. Res., 119, 11729-11742, doi:10.1002/2014JD022034, 2014.

Ebmeier, S. K., Sayer, A. M., Grainger, R. G., Mather, T. A., and Carboni, E.: Systematic satellite observations of the impact of 
aerosols from passive volcanic degassing on local cloud properties, Atmos. Chem. Phys., 14, 10601-10618, doi:10.5194/acp14-10601-2014, 2014.

Folch, A., Costa, A., and Basart, S.: Validation of the FALL3D ash dispersion model using observations of the 2010 Eyjafjallajöekull volcanic ash clouds, Atmos. Environ., 48, 165-183, 2012.

Gagné, S., Lehtipalo, K., Manninen, H. E., Nieminen, T., Schobesberger, S., Franchin, A., Yli-Juuti, T., Boulon, J., Sonntag, A., Mirme, S., Mirme, A., Hõrrak, U., Petäjä, T., Asmi, E., and Kulmala, M.: Intercomparison of air ion spectrometers: an evaluation of results in varying conditions, Atmos. Meas. Tech., 4, 805-822, doi:10.5194/amt-4-805-2011, 2011.

Galle, B., Johansson, M., Rivera, C., Zhang, Y., Kihlman, M., Kern, C., Lehmann, T., Platt, U., Arellano, S., and Hidalgo, S.: Network for Observation of Volcanic and Atmospheric Change (NOVAC)A global network for volcanic gas monitoring: Network layout and instrument description, J. Geophys. Res., 115, D05304, doi:10.1029/2009JD011823, 2010.

Halmer, M. M., Schmincke, H.-U., and Graf, H.-F.: The annual volcanic gas input into the atmosphere, in particular into the stratosphere: a global data set for the past 100 years, J. Volcanol. Geoth. Res., 115, 511-528, doi:10.1016/S0377-0273(01)003183, 2002.

Hamonou, E., Chazette, P., Balis, D., Dulac, F., Schneider, X., Galani, E., Ancellet, G., and Papayannis, A.: Characterization of the vertical structure of Saharan dust export to the Mediterranean basin, J. Geophys. Res., 104, 18257-22270, 1999.

Hanna, S. R.: Applications in air pollution modeling, in: Atmospheric Turbulence and Air Pollution Modelling, edited by: Nieuwstadt, F. T. M., Van Dop, H., and Reidel, D., Publishing Company, Dordrecht, Holland, 1982.

Hibert, C., Mangeney, A., Polacci, M., Di Muro, A., Vergniolle, S., Ferrazzini, V., Taisne, B., Burton, M., Dewez, T., Grandjean, G., Dupont, A., Staudacher, T., Brenguier, F., Shapiro, N., Kowalski, P., Boissier, P., Catherine, P., and Lauret, F.: Multidisciplinary monitoring of the January 2010 eruption of Piton de la Fournaise volcano, La Réunion island, J. Geophys. Res., 120, 3026-3047, doi:10.1002/2014JB011769, 2015.

Hirsikko, A., Bergman, T., Laakso, L., Dal Maso, M., Riipinen, I., Hõrrak, U., and Kulmala, M.: Identification and classification of the formation of intermediate ions measured in boreal forest, Atmos. Chem. Phys., 7, 201-210, doi:10.5194/acp-7-201-2007, 2007

Hobbs, P., Tuell, J., Hegg, D., Radke, L., and Eltgroth, M.: Particles and gases in the emissions from the 1980-1981 volcanic eruptions of Mt. St. Helens, J. Geophys. Res., 87, 11062-11086, 1982.

Kaminski, E., Tait, S., Ferrucci, F., Martet, M., Hirn, B., and Husson, P.: Estimation of ash injection in the atmosphere by basaltic volcanic plumes: The case of the Eyjafjallajökull 2010 eruption, J. Geophys. Res.-Sol. Ea., 116, B00C02, doi:10.1029/2011JB008297, 2011

Kern, C., Kick, F., Lübcke, P., Vogel, L., Wöhrbach, M., and Platt, U.: Theoretical description of functionality, applications, and limitations of $\mathrm{SO}_{2}$ cameras for the remote sensing of volcanic plumes, Atmos. Meas. Tech., 3, 733-749, doi:10.5194/amt-3733-201, 2010.
Knobelspiesse, K., Pietras, C., and Fargion, G.: Sun-Pointing-Error Correction for Sea Deployment of the MICROTOPS II Handheld Sun Photometer, J. Atmos. Ocean. Technol., 20, 767-771, 2003.

Lenat, J.: Construction of La Réunion, in: Active volcanoes of the Southwest Indian Ocean: Piton de la Fournaise and Karthala, Active volcanoes of the world (Chap. 3), edited by: Bachelery, P., Lenat, J. F, Di Muro, A., and Michon, L., Springer, Berlin, doi:10.1007/978-3-642-31395-0_3, 2016.

Lesouëf, D., Gheusi, F., Delmas, R., and Escobar, J.: Numerical simulations of local circulations and pollution transport over Reunion Island, Ann. Geophys., 29, 53-69, doi:10.5194/angeo-2953-2011, 2011.

Mäkelä, J., Riihelä, M., Ukkonen, A., V. Jokinen, V., and Keskinen, J.: Comparison of mobility equivalent diameter with KelvinThomson diameter using ion mobility data, J. Chem. Phys., 105, 1562-1571, 1996.

Marti, J., Jefferson, A., Cai, X., Richert, C., McMurry, P., and Eisele, F.: $\mathrm{H}_{2} \mathrm{SO}_{4}$ vapor pressure of sulfuric acid and ammonium sulphate solutions, J. Geophys. Res., 102, 3725-3735, doi:10.1029/96JD03064, 1997.

Martin, R., Mather, T., Pyle, D., Power, M., Allen, A., Aiuppa, A., Horwell, C., and Ward, E.: Composition-resolved size distributions of volcanic aerosols in the Mt. Etna plumes, J. Geophys. Res., 113, D17211, doi:10.1029/2007JD009648, 2008.

Mather, T., Pyle, D., and Oppenheimer, C.: Tropospheric Volcanic Aerosol, Geophys. Mono., 139, 189-212, doi:10.1029/139GM12, 2005.

Michon, L., Saint-Ange, F., Bachèlery, P., Villeneuve, N., and Staudacher, T.: Role of the structural inheritance of the oceanic lithosphere in the magmato-tectonic evolution of Piton de la Fournaise volcano (La Réunion Island), J. Geophys. Res., 112, B04205, doi:10.1029/2006JB004598, 2007.

Michon, L., Di Muro, A., Villeneuve, N., Saint-Marc, C., Fadda, P., and Manta, F.: Explosive activity of the summit cone of Piton de la Fournaise volcano (La Réunion island): A historical and geological review, J. Volcanol. Geotherm. Res., 264, 117-133, 2013.

Michon, L., Ferrazzini, V., Di Muro, A., Villeneuve, N., and Famin, V.: Rift zones and magma plumbing system of Piton de la Fournaise volcano: how do they differ from Hawaii and Etna, J. Volcanol. Geotherm. Res., 303, 112-129, 2015.

Mikkonen, S., Romakkaniemi, S., Smith, J., Korhonen, H., Petäjä, T., Plass-Duelmer, C., Boy, M., McMurry, P., Lehtinen, K., Joutsensaari, J., Hamed, A., III, R. M., Birmili, W., Spindler, G., Arnold, F., Kulmala, M., and Laaksonen, A.: A statistical proxy for sulphuric acid concentration, Atmos. Chem. Phys., 11, 11319-11334, doi:10.5194/acp-11-11319-2011, 2011.

Ort, M., Di Muro, A., Michon, L., and Bachelery, P.: Explosive eruptions from the interaction of magmatic and hydrothermal systems during flank extension: the Bellecombe Tephra of Piton de la Fournaise (La Réunion Island), Bull. Volcanol., 78, 1-14, doi:10.1007/s00445-015-0998-8, 2016.

Peltier, A., Bachèlery, P., and Staudacher, T.: Magma transport and storage at Piton de La Fournaise (La Réunion) between 1972 and 2007: A review of geophysical and geochemical data, J. Volcanol. Geotherm. Res., 184, 93-108, 2009.

Peltier, A., Bianchi, M., Kaminski, E., Komorowski, J.-C., Rucci, A., and Staudacher, T.: PSInSAR as a new tool to monitor pre-eruptive volcano ground deformation: Validation using GPS 
measurements on Piton de la Fournaise, Geophys. Res. Lett., 37, 112301, doi:10.1029/2010GL043846, 2010.

Peltier, A., Massin, F., Bachèlery, P., and Finizola, A.: Internal structures and building of basaltic shield volcanoes: The example of the Piton de La Fournaise terminal cone (La Réunion), Bull. Volcanol., 74, 1881-1897, doi:10.1007/s00445-012-0636-7, 2012.

Peltier, A., Beauducel, F., Villeneuve, N., Ferrazzini, V., Di Muro, A., Derrien, A., Jourde, K., and Taisne, B.: Deep fluid transfer evidenced by surface deformation during the 2014-2015 unrest at Piton de la Fournaise volcano, J. Volcanol. Geotherm. Res., 321, 140-148, doi:10.1016/j.jvolgeores.2016.04.031, 2016.

Penner, J., Andreae, M., Annegarn, H., Barrie, L., Feichter, J., Hegg, D., Jayaraman, A., Leaitch, R., Murphy, D., Nganga, J., and Pitari, G.: Aerosols, their direct and indirect effects, Climate Change: The scientific basis, edited by: Houghton, J. T., Ding, Y., Griggs, D. J., Noguer, M., Van der Linden, P. J., Dai, X., Maskell, K., and Johnson, C. A., Cambridge University Press, UK, 289-349, 2001.

Pietras, C., Knobelspiesse, K. D., Frouin, R., Holben, B., and Voss, K.: Calibration of Sun photometers and sky radiance sensors, in: Ocean Optics Protocols for Satellite Ocean Color Sensor Validation, Revision 3, edited by: Mueller, L. and Fargion, G. S., NASA Tech. Memo., TM-20021-210004, 1, 76-90, 2002.

Pirjola, L., Kulmala, M., Wilck, M., Bischoff, A., Stratmann, F., and Otto, E.: Formation of sulphuric acid aerosols and cloud condensation nuclei: An expression for significant nucleation and model comparison, J. Aerosol Sci., 30, 1079-1094, 1999.

Pisani, G., Boselli, A., Coltelli, M., Leto, G., Pica, G., Scollo, S., Spinelli, N., and Wang, X.: Lidar depolarization measurement of fresh volcanic ash from Mt. Etna, Italy, Atmos. Environ., 62, 34-40, 2012.

Ripepe, M., Bonadonna, C., Folch, A., Donne, D. D., Lacanna, G., Marchetti, E., and Höskuldsson, A.: Ash-plume dynamics and eruption source parameters by infrasound and thermal imagery: The 2010 Eyjafjallajökull eruption, Earth Planet. Sci. Lett., 366, 112-121, doi:10.1016/j.eps1.2013.02.005, 2013.

Robock, A.: Volcanic eruptions and climate, Rev. Geophys., 38, 191-219, 2000

Rose, W. I., Millard, G. A., Mather, T. A., Hunton, D. E., Anderson, B., Oppenheimer, C., Thornton, B. F., Gerlach, T. M., Viggiano, A. A., Kondo, Y., Miller, T. M., and Ballenthin, J. O.: Atmospheric chemistry of a 33-34 hour old volcanic cloud from Hekla Volcano (Iceland): Insights from direct sampling and the application of chemical box modeling, J. Geophys. Res.-Atmos., 111, D20206, doi:10.1029/2005JD006872, 2006.

Roult, G., Peltier, A., Taisne, B., Staudacher, T., Ferrazzini, V., and Di Muro, A.: A new comprehensive classification of the Piton de la Fournaise eruptions spanning the 1986-2011 period, Search and analysis of eruption precursors from a broad-band seismological station, J. Volcanol. Geotherm. Res., 241/242, 78-104, 2012.

Salerno, G., Burton, M., Oppenheimer, C., Caltabiano, T., Randazzo, D., Bruno, N., and Longo, V.: Three-years of $\mathrm{SO}_{2}$ flux measurements of Mt. Etna using an automated UV scanner array: Comparison with conventional traverses and uncertainties in flux retrieval, J. Volcanol. Geoth. Res., 183, 76-83, doi:10.1016/j.jvolgeores.2009.02.013, ISSN 0377-0273, 2009.

Sandu, I., Brenguier, J.-L., Thouron, O., and Stevens, B.: How important is the vertical structure for the representation of aerosol impacts on the diurnal cycle of marine stratocumulus?, Atmos. Chem. Phys., 9, 4039-4052, doi:10.5194/acp-9-4039-2009, 2009.

Seity, Y., Brousseau, P., Malardel, S., Hello, G., Bénard, P., Bouttier, F., Lac, C., and Masson, V.: The AROME-France ConvectiveScale Operational Model, Month. Weather Rev., 139, 976-991, doi:10.1175/2010MWR3425.1, 2011.

Smirnov, A., Holben, B. N., Eck, T. F., Dubovik, O., and Slutsker, I.: Cloud screening and quality control algorithms for the AERONET database, Remote Sens. Environ., 73, 337-349, 2000.

Staudacher, T. and Peltier, A.: Ground deformation at Piton de la Fournaise (La Réunion Island), a review from 20 years of GNSS monitoring, in: Active volcanoes of the Southwest Indian Ocean: Piton de la Fournaise and Karthala. Active volcanoes of the world, edited by: Bachelery, P., Lenat, J. F, Di Muro, A., and Michon, L., Springer, Berlin, doi:10.1007/978-3-642-313950_9, 2015.

Staudacher, T., Ferrazzini, V., Peltier, A., Kowalski, P., Boissier, P., Catherine, P., Lauret, F., and Massin, F.: The April 2007 eruption and the Dolomieu crater collapse, two major events at Piton de la Fournaise (La Réunion Island, Indian Ocean), J. Volcanol. Geotherm. Res., 184, 126-137, doi:10.1016/j.jvolgeores.2008.11.005, 2009.

Staudacher, T., Peltier, A., Ferrazzini, V., Di Muro, A., Boissier, P., Catherine, P., Kowalski, P., and Lauret, F.: Fifteen years of intense eruptive activity (1998-2013) at Piton de la Fournaise Volcano. In Active volcanoes of the Southwest Indian Ocean: Piton de la Fournaise and Karthala. Active volcanoes of the world, edited by: Bachelery, P., Lenat, J. F., Di Muro, A., and Michon, L., Springer, Berlin, doi:10.1007/978-3-642-31395-0_15, 2015.

Stevens, B., Cotton, W. R., Feingold, G., and Moeng, C.H.: Large-eddy simulations of strongly precipitating, shallow, stratocumulus-topped boundary layers, J. Atmos. Sci., 55, 36163638, 1998.

Stohl, A., Forster, C., Frank, A., Seibert, P., and Wotawa, G.: Technical note: The Lagrangian particle dispersion model FLEXPART version 6.2, Atmos. Chem. Phys., 5, 2461-2474, doi:10.5194/acp-5-2461-2005, 2005.

Tulet, P. and Villeneuve, N.: Large scale modeling of the transport, chemical transformation and mass budget of the sulfur emitted during the April 2007 eruption of Piton de la Fournaise, Atmos. Chem. Phys., 11, 4533-4546, doi:10.5194/acp-11-45332011, 2011.

Villeneuve, N. and Bachèlery, P.: Revue de la typologie des éruptions au Piton de la Fournase, processus et risqué volcaniques associés, Cybergeo: European Journal of Geography, Environnement, Nature, Paysage, p. 336, http://cybergeo.revues.org/ index2536.html, 2006.

Wiedensohler, A., Birmili, W., Nowak, A. et al.: Particle mobility size spectrometers: harmonization of technical standards and data structure to facilitate high quality long-term observations of atmospheric particle size distributions, Atmos. Meas. Tech., 5, 657-685, doi:10.5194/amt-5-657-2012, 2012. 